\title{
Francisco Franco y los reyes godos: la legitimación del poder usurpado por medio de la ceremonia y la música ${ }^{1}$
}

\author{
Francisco Franco and the Gothic kings: \\ The Legitimation of Usurped Power \\ through Ceremony and Music
}

Este trabajo estudia el empleo de la música en la manipulación del pasado histórico. En concreto, se estudia el uso político y simbólico del canto y la liturgia hispánicos por el franquismo para justificar el acceso a un poder adquirido de manera ilegítima. El sistema de propaganda del régimen franquista recurrió con frecuencia a la simbología imperial en las ceremonias de estado como una de sus principales representaciones de poder. La primera de estas ceremonias fue la celebración de la victoria en la Guerra Civil, que culminó en mayo de 1939 con una fastuosa acción de gracias en la que se empleó el ritual visigodo para la unción de reyes, un ritual cargado de simbolismo con el que se intenta mostrar a Franco como "rey ungido" y resaltar su continuidad con la monarquía histórica hispánica. En la ceremonia se empelaron símbolos, gestos y repertorio litúrgico-musical del ritual de coronación de los reyes visigodos. Este repertorio se tomó de manuscritos medievales cuyas melodías no se pueden transcribir debido a que su notación musical no indica la altura de los sonidos. Por ello, y tal y como sucedió con otras restauraciones coetáneas (espacios arquitectónicos, reliquias, tipografias, etc.), se recrearon varias melodías presuntamente visigodas para transmitir un mensaje de tradición y continuidad con la realeza histórica.

Palabras clave: monarquía visigoda, dictadura franquista, ceremonia, música, liturgia hispánica, símbolos y representación del poder, propaganda.

This article examines the use of music in the manipulation of the historical past. Specifically, it studies the Francoist political and symbolic use of Hispanic chant and the Hispanic liturgy to justify access to power obtained in an illegitimate way. The Francoist regime's system of propaganda often resorted to imperial symbology in state ceremonies as one of its main representations of power. The first of these ceremonies was the celebration of the victory in the Civil War, which culminated in May 1939 with a lavish thanksgiving in which the Visigoth ritual was used to anoint kings, a ritual filled

${ }^{1}$ Este artículo ha sido realizado en el marco del proyecto de I+D HAR2017-82931-P. Agradezco a Ismael Fernández de la Cuesta, Gemma Pérez Zalduondo, Pilar Ramos, Don Randel, Juan Pablo Rubio, al monasterio de Santo Domingo de Silos, en especial al P. Norberto Núnez, así como a los revisores anónimos de la revista sus comentarios y aportaciones. 
with symbolism employed to try to depict Franco as an "anointed king" and emphasise his continuity with the Spanish historical monarchy. Symbols, gestures and liturgical-musical repertory from the coronation ritual of the Visigothic kings were used during the ceremony. This repertory was taken from Medieval manuscripts whose melodies cannot be transcribed as their music notation does not indicate pitch. For this reason, and as occurred with other reconstructions of the time (architectonic spaces, relics, fonts, etc.), several suposed Visigothic melodies were recreated in order to transmit a message of tradition and continuity with historical royalty.

Keywords: Visigothic monarchy, Francoist dictatorship, ceremony, ceremonial music, Spanish liturgy, symbols and the representation of power, propaganda.

\section{Los visigodos, la liturgia hispánica, el imperio y la propaganda en el franquismo}

Ataúlfo, Sigérico, Walia, Teodorico, Turismundo..., los niños españoles de varias generaciones tuvieron que aprenderse la lista cronológica de los treinta y seis reyes del reino visigodo en la península ibérica desde el año 410 al 711. Esta lista se ha convertido en un tópico de la historia de la educación en España, pues presenta la historia como un absurdo y acrítico ejercicio de memoria en el que se ignora todo de los personajes recitados, salvo el nombre. Pero aprender esa lista tenía un sentido: recordar el pasado godo, cuya supuesta gloria ha sido utilizada a menudo en la historia de España desde el siglo IX hasta la actualidad ${ }^{2}$ y cuya principal manipulación fue crear el llamado "mito gótico", que sostiene la imaginaria continuidad de los reyes de España desde los visigodos -obviando, claro está, el origen germano de estos- e identifica la unidad del país con el cristianismo y con la más arcaica y pura esencia hispana.

El objeto de este trabajo es estudiar el empleo de la música en la manipulación del pasado histórico para justificar un poder adquirido de manera ilegítima. En concreto, se estudia el uso político y simbólico del canto y la liturgia hispánicos, un tema no tratado hasta ahora en las investigaciones acerca del uso político de la música por parte del franquismo ${ }^{3}$. El marco de

\footnotetext{
${ }^{2}$ Santiago Abascal, líder del partido ultraderechista español Vox, participó en Italia en la fiesta del partido neofascista Fratelli d'Italia. Declaró allí -entre otras cosas- que no todas las religiones valen lo mismo y comparó la inmigración irregular en España con la invasión musulmana del reino visigodo, El País, 22-9-2019 (https://elpais.com/politica/2019/09/22/actualidad/1569175849_637199.html, consulta 10-1-2020).

${ }^{3}$ En este tema destacan las obras de Gemma Pérez Zalduondo: "Ideología y política en las instituciones musicales españolas durante la segunda república y primer franquismo", Quintana: Revista de Estudios do Departamento de Historia da Arte, 5, 5, 2006, pp. 145-156; -: "La música en los intercambios culturales entre España y Alemania (1938-1942)", Cruces de caminos: intercambios musicales y artísticos en la Europa de la primera mitad del siglo XX, Gemma Pérez Zalduondo, María Isabel Cabrera García (eds.), Granada, Universidad de Granada, 2010, pp. 407-452; -: "El imperio de la propaganda. La música en los fastos conmemorativos del primer franquismo", Discursos y prácticas musicales nacionalistas (1900-1970), Pilar Ramos López (ed.), Logroño, Universidad de La Rioja, 2012, pp. 339-361; - : Una música para el "Nuevo Estado". Música, ideología y política en el primer franquismo,
} 
referencia utilizado serán los estudios sobre la construcción del poder y su aparato simbólico en el imperio visigodo ${ }^{4}$, en el franquismo de la primera posguerra ${ }^{5}$ y la relación entre ambos. Se estudiarán sus sustentos teóricos, sus posibles artífices y la aplicación del mito gótico y su narración propagandística en el caso estudiado: el empleo de supuesta música visigoda en ceremonias de estado franquistas.

Uno de los elementos más importantes del mito gótico fue la liturgia, ya que, tras la conversión de Recaredo, los reyes de España pasaron a ser paladines de la religión católica y de una liturgia autóctona y diferente de la franco-romana -o gregoriana-: la liturgia "hispánica", sancionada por grandes padres de la iglesia como San Isidoro y San Leandro de Sevilla. La implicación de la religión católica en la política visigoda, hizo que la liturgia fuera además uno de los principales símbolos del poder real. Esta liturgia -supuestamente mantenida en los siglos de dominación musulmana por la comunidad mozárabe-, ha sido considerada desde la Edad Media testimonio de una presunta identidad hispana y se ha mostrado como heredera del prestigio y autoridad del antiguo reino visigodo. Si bien en la Edad Media la liturgia hispánica sufrió sospechas de herejía - que culminaron con la furibunda respuesta de Beato de Liébana que originó los famosos manuscritos conocidos como "Beatos"-, pronto quedó demostrado que era perfectamente ortodoxa, no tras muchas complicaciones que aquí no viene al caso detallar.

Libargo, 2013; Gemma Pérez Zalduondo, María Isabel Cabrera García: "Voices, Strategies and Practices of Propaganda Music and Artistic Culture at the Service of the State during Francoism", Music and Propaganda in the Short Twentieth Century, Massimiliano Sala (ed.), Turnhout, Brepols, 2014, pp. $207-$ 224. También son de referencia Ignacio Henares Cuéllar, José Castillo Ruiz, Gemma Pérez Zalduondo, María Isabel Cabrera García (eds.): Dos décadas de cultura artística en el franquismo (1936-1956), Granada, Universidad de Granada, 2001; Emilio Casares, Javier Suárez-Pajares (eds.): Música española entre dos guerras, 1914-1945, Granada, Archivo Manuel de Falla, 2002; Gemma Pérez Zalduondo, Germán Gan Quesada (eds.): Music and Francoism, Turnhout, Brepols, 2013; Belén Vega Pichaco, Elsa Calero Carramolino, Gemma Pérez Zalduondo (eds.): Puentes sonoros y coreográficos durante el franquismo. Imaginarios, intercambios y propaganda en clave internacional, Granada, Libargo, 2019.

${ }^{4}$ Véase la bibliografía al respecto comentada en las notas 57, 62, 65, 66 y 67.

${ }^{5}$ Zira Box: España, Año Cero. La construcción simbólica del franquismo, Madrid, Alianza, 2010; Francisco Sevillano Calero: "La propaganda y la construcción de la cultura de guerra en España durante la guerra civil", Studia Historica: Historia Contemporánea, 32, 2014, pp. 225-237; Francisco José Moreno Martín (coord.): El franquismo y la apropiación del pasado. El uso de la historia, de la arqueología y de la historia del arte para la legitimación de la dictadura, Madrid, Pablo Iglesias, 2017; Francisco José Moreno Martín: "Gesta Dei per Hispanos. Invención, visualización e imposición del mito de Cruzada durante la Guerra Civil y el primer franquismo", La Reconquista: ideología y justificación de la guerra santa peninsular, Carlos de Ayala Martínez, Isabel Cristina Ferreira Fernandes, J. Santiago Palacios Ontalva (coords.), 2019, pp. 483-518.

${ }^{6}$ No discutiré aquí las denominaciones de esta liturgia. Empleo el término "hispánico" para referirme a la antigua liturgia, sus ritos y cantos. La palabra "mozárabe" referida a eso mismo la empleo entrecomillada. 
La liturgia hispánica fue suprimida en el siglo XI y sustituida por el canto franco-romano, pero se mantuvo con permiso civil y eclesiástico en la ciudad de Toledo -donde se denomina hasta hoy "canto mozárabe"-.Allí, su uso fue reduciéndose por la debilidad de la comunidad que la sustentaba, aunque todavía en el siglo XIV se copiaron libros litúrgicos tomando como modelos los del siglo $\mathrm{X}^{7}$.Varios cardenales intentaron mantener y recuperar esta liturgia en distintos momentos entre los siglos XIII y XX, destacando en ello el cardenal Cisneros, que consiguió editar sus textos a partir de las fuentes medievales $^{8}$ y pretendió también recuperar su música, para lo cual ordenó copiarla en varios cantorales. Sin embargo, cuando se quiso realizar esta copia, se constató la ilegibilidad de las melodías medievales debido a que su notación es adiastemática - esto es, no indica las alturas melódicas- y a que la reducida comunidad mozárabe toledana había perdido la tradición oral de la mayor parte del repertorio ${ }^{9}$. El problema se resolvió creando unas melodías que denominaré neomozárabes ${ }^{10}$ y que son -con algunas excepciones que sí parecen ser de origen medieval-, una construcción basada en la repetición de fórmulas melódicas o en el uso de cantilados recto tono. Es más, tras la copia de los Cantorales de Cisneros, los capellanes mozárabes tampoco interpretaban la música escrita en ellos, sino versiones simplificadas, adaptadas por ellos mismos ${ }^{11}$.

La Historia Gothorum ${ }^{12}$ de Isidoro de Sevilla (ca.624) elabora y defiende la identidad gótica de Hispania unida bajo la misma corona y muestra una identidad y orgullo hispanos, especialmente en su prólogo, Laus Hispaniae. La Crónica Albeldense (ca. 881), escrita bajo el reinado de Alfonso III, plasma la teoría de la reconquista creada por los clérigos mozárabes de la época, que reivindica la herencia visigoda en el reino de Asturias con una genealogía mítica de Pelayo, al que convierte en tío del último rey godo, Rodrigo. La Crónica encomienda a los reyes cristianos la tarea de vencer a los musulmanes, enemigos de la fe, y afirma, además, que Alfonso II restauró en su reino de

\footnotetext{
${ }^{7}$ Mundó data entre finales del siglo XII y principios del XIV varios libros litúrgicos toledanos que parecen imitar los del siglo X y que muestran que el repertorio seguía en uso en esa fecha. Anscari M. Mundó: "La datación de los códices litúrgicos visigóticos toledanos", Hispania Sacra, XVIII, 35, 1965, pp. 1-25.

${ }^{8}$ Missale mixtum secundum regulam beati Isidori, dictum mozarabes, Toledo, Melchor Gorricio, Pedro Hagenbach, 1500; Breviarium secundum regulam beati Isidori, Toledo, idem, 1502.

${ }^{9}$ Carmen Julia Gutiérrez: "El canto mozárabe como modelo de construcción de una identidad nacional", Mélanges de la Casa de Velázquez, 2019, 49, 1 pp. 185-222; Miguel Ángel López Fernández: Los Cantorales de Cisneros, tesis doctoral, Universidad Complutense de Madrid, 2019.

${ }^{10}$ Sigo la denominación creada por Vito D. Imbasciani: Cisneros and the Restoration of the Mozarabic Rite, tesis doctoral, Cornell University, 1979.

${ }^{11}$ Como siguen haciéndolo todavía hoy en día, véase C. J. Gutiérrez: "El canto mozárabe...", pp. 198-200.

${ }^{12}$ Isidoro de Sevilla: "Historia de regibus Gothorum, Vandalorum et Suevorum", Monumenta Germaniae Historica, Auctores Antiquissimi, vol. 11, Berlín, 1894, pp. 241-303.
} 
Oviedo el ceremonial de la corte visigoda toledana "así en la iglesia como en el palacio de Oveto, adoptó todo el orden y ceremonial de los godos, tal como había sido en Toledo"13.

El goticismo se ve en casi todas las crónicas del siglo XIII. Lucas de Tui en $1236^{14}$ denomina a las tropas de la corona de Castilla el gothorum exercitus, lo cual relaciona estrechamente la tradición visigótica y la realidad castellano leonesa de su tiempo ${ }^{15}$. Jiménez de Rada en $1243^{16}$ insiste en que los monarcas castellanos eran los dirigentes más autorizados para recibir el legado de la España goda ${ }^{17}$. Alonso de Cartagena, obispo de Burgos, llegó a establecer en $1456^{18}$ una línea sucesoria directa entre los reyes godos y los de su tiempo partiendo de Suintila -que expulsó a los bizantinos-, seguía con Pelayo -que resistió a los musulmanes- y, lógicamente, acababa con su rey, Enrique IV. También los visigodos simbolizan la presunta España unida para los Reyes Católicos, que jamás usaron el título de Reyes "de España” ya que jurídicamente España no existía, aunque sí el sentimiento de pérdida de unidad territorial tras la invasión musulmana y la necesidad de volver a la unidad visigoda ${ }^{19}$. En los siglos XVI y XVII los historiadores de la monarquía reivindican para Castilla un papel preponderante en la política peninsular insistiendo en la continuidad del linaje real desde época goda para defenderse de las pretensiones territoriales de sus vecinos ${ }^{20}$. Lo mismo sucede con la dinastía Borbón en 1700, que patrocina la construcción de una nueva historia nacional basada en los documentos. Para Burriel, ejecutor del proyecto, la liturgia era un componente esencial de la historia patria y de ahí su interés en los manuscritos litúrgicos hispánicos ${ }^{21}$. Los reyes españoles usaron el título de Reyes Godos hasta la Constitución de 1812.

\footnotetext{
${ }^{13}$ Crónicas Asturianas, Juan Gil Fernández, José L. Moralejo y Juan I. Ruiz de la Peña (eds.), Oviedo, Servicio de Publicaciones de la Universidad de Oviedo, 1985, p. 249.

${ }^{14}$ Lucas Tudensis: Chronicon mundi, Corpus Christianorum Continuatio Mediaevalis (CCCM 74), Emma Falque Rey (ed.), Turnhout, Brepols Publishers, 2006.

${ }^{15}$ Julio Valdeón: Las raíces medievales de España, Real Academia de la Historia, 2002, pp. 70-73.

${ }^{16}$ Rodrigo Jiménez de Rada: Historia de los hechos de España, Introducción, traducción, notas e índices de Juan Fernández Valverde, Madrid, Alianza Editorial, 1989.

${ }^{17}$ José Antonio Maravall: El concepto de España en la Edad Media, Centro de Estudios Políticos y Constitucionales, 1997 (1. edición 1954), pp. 320-325.

${ }^{18}$ Yolanda Espinosa Fernández: La Anacephaleosis de Alonso de Cartagena: edición, traducción, estudio, tesis doctoral, Universidad Complutense de Madrid, 1989.

${ }^{19}$ Sin embargo, otras naciones europeas sí percibían esa nueva realidad peninsular y en muchos documentos o tratados internacionales se dirigen a los reyes "de España", José María de Francisco Olmos: "Estudio documental de la moneda castellana de Juana la Loca fabricada en los Países Bajos (1505-1506)", Revista General de Información y Documentación, 12-2, 2002, pp. 295-296, p. 295.

${ }^{20}$ Martín Ríos Saloma: La Reconquista. Una construcción historiográfica (siglos XVI-XIX), Madrid, Marcial Pons Historia, 2011, pp. 47 y ss.

${ }^{21}$ Como explica Susan Boynton: Silent Music. Medieval Song and the Construction of History in Eighteenth-Century Spain, Nueva York, Oxford University Press, 2011.
} 
También para la dictadura franquista el reino visigodo fue un referente de centralismo y un instrumento para legitimar, por medio de la invención de una tradición, la construcción nacional. Como la unidad e identidad de España no se podía basar en sus variopintos paisajes, costumbres o lenguas, serán el catolicismo y la dictadura los que aseguren "la continuidad histórica de la nación, sometida jerárquicamente a Dios"22, pues si una nación no es natural debe ser cultural y simbólica ${ }^{23}$. Así, la dictadura, para legitimarse, imitó los símbolos de la monarquía y asumió su carácter cristiano, tradicional y continuado desde la Edad Media. Por eso la propaganda y el simbolismo franquista tuvieron siempre presentes los aspectos que resaltaban el carácter imperial del Gobierno inspirándose en el primer imperio cristiano español, el visigodo ${ }^{24}$-también, sobre todo en arquitectura, en el de Felipe II-. La simbología imperial se manifestó en especial en las ceremonias, el medio de comunicación del sistema propagandístico franquista. En ellas se unió lo político, lo religioso y lo militar, todo ello aliñado con la megalomanía de Franco y su gusto por la pompa ¿En qué momento sino en una ceremonia podría haberse empleado todo ese fasto y las grandiosas construcciones efímeras de adobe pintado? (ilustración 1).

La creación del culto a la personalidad de Franco -su carácter providencial, su magnanimidad, clarividencia, e incluso poderes taumatúrgicos-, fue obra de Ramón Serrano Suñer, ministro encargado de la Delegación Nacional de Prensa y Propaganda, y destacó plasmándola en la prensa, Ernesto

\footnotetext{
${ }^{22}$ Xosé M. Núñez Seixas: "De gaitas y liras: sobre discursos y prácticas de la pluralidad territorial en el fascismo español (1930-1950)", Falange. Las culturas politicas del fascismo en la España de Franco (19361975), Miguel Ángel Ruiz Carnicer (ed.), Zaragoza, IFC, 2013, pp. 289-316 (p. 300).

${ }^{23}$ José Antonio Muñiz Velázquez: "La Música en el Sistema Propagandístico Franquista", Historia y comunicación social, 3, 1998, pp. 343-364 (p. 344).

${ }^{24}$ Incluso tomando tipos de letra germanófilos en los carteles. En 1939 el Gobierno usaba las tipografías sin serifa, que estaban de moda (Futura, Elektra, Ibérica, Clásico nacional o Ibarra), pero enseguida la oficina de prensa franquista empezó a usar tipografías góticas (Blackletter, Fraktur u Old English), muy características por su contraste entre rasgos gruesos y finos, como hechos a pluma y los remolinos de las serifas. Este era el tipo que había usado Gutemberg en su Biblia y se había empleado en Alemania hasta principios del siglo XX, cuando fue sustituido por los tipos sin serifa, que a su vez fueron prohibidos en 1933 por Hitler, por ser "no alemanas". Así, la gótica, el tipo de letra alemán fue empleada de nuevo hasta 1941, cuando dejó de usarse porque el Reich consideraba que, como futura potencia mundial, debía adaptar el tipo internacional de letra. Helena Carazo: Vota SANS SERIF. Análisis de tipografías electorales (https://issuu.com/caralena/docs/catalogo_issuu, consulta 101-2020); Peter Bain, Paul Shaw: La letra gótica, tipo e identidad nacional, Valencia, Campgràfic Editors, 2003; José Ramón Penela y Dimas García Moreno: "Tipografía Española 1900-1936", Tipografía y diseño editorial en Zamora. De Centenera al siglo XXI, catálogo de la exposición, Zamora, Biblioteca Pública del Estado, 2004.
} 
Giménez Caballero ${ }^{25}$. A la recreación del poder imperial de Franco contribuyó el uso de símbolos personales como la capa con cuello de piel con la que aparece en el cartel oficial de la victoria -que lo presentaba como un rey- (ilustración 2), el bastón de mando -que recuerda al cetro-, el uso del palio -reservado a reyes y pontífices y que usó desde el primer día- o las ceremonias propias de reyes medievales.

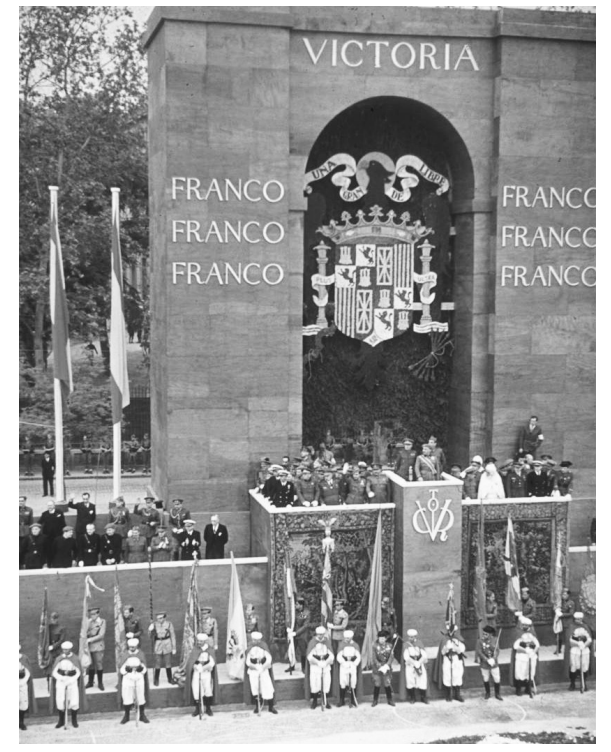

Ilustración 1. Arquitectura efímera de adobe pintado, Desfile de la victoria, 1939

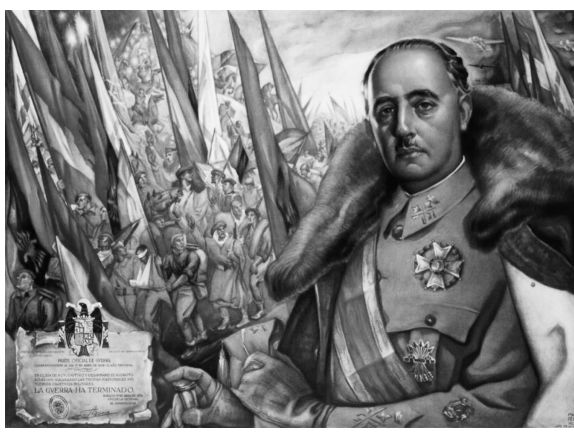

Ilustración 2. Cartel oficial de la victoria, 1939

Franco se presentó pues ante los españoles como continuador de la línea monárquica y con la imagen de cruzado medieval (ilustración 3), del nuevo Cid, del defensor de la fe frente al enemigo (bizantinos, musulmanes, judíos, masones, rojos ${ }^{26}$. Como propone Giuliana di $\mathrm{Febo}^{27}$, el empleo de la termino-

25 "Una de las tareas de Serrano consistió en exaltar a Franco, consolidando su imagen como el jefe heroico de una 'Cruzada' que había liberado a España de las hordas ateas de Moscú. Los textos para la identificación de Franco con los grandes héroes del pasado de España fueron obra de muchas plumas, incluidas las de Fermín Yzurdiaga, Ernesto Giménez Caballero e incluso Dionisio Ridruejo. Pero, por encima de todo, el creador de la leyenda de Franco como "Caudillo" providencial fue Serrano, que se sirvió de la prensa y del aparato de propaganda que controlaba". Paul Preston: "Ramón Serrano Suñer", En el combate por la historia. La República, la guerra civil, el franquismo, Ángel Viñas (ed.), Barcelona, Pasado \& Presente, pp. 887-902 (p. 891).

26 "Las dos ciudades", carta pastoral del obispo de Salamanca Enrique Plá y Deniel del 30-9-1936, fue la primera adhesión importante de la jerarquía eclesiástica al golpe de Estado, en ella se refiere por primera vez a la "cruzada contra los hijos de Caín".

${ }^{27}$ Giuliana di Febo: Ritos de guerra y de victoria en la España Franquista, Bilbao, Desclée de Brouwer, 2002, pp. 97 y ss. 
logía martirial aplicada a la guerra (calvario, agonía, martirio), la exaltación de los "mártires de la cruzada" y la glorificación de lo militar transforma las celebraciones de la victoria en ritos de reconquista.

Esta imagen fue apoyada por la Iglesia que, desde el principio, se le mostró abiertamente favorable y sancionó el carácter providencial de su victoria, su carácter de "elegido" y su "misión divina", tanto la jerarquía española -destacando el Cardenal Primado de España, Isidro Gomá28-, como el propioVaticano que, aunque al principio fue más moderado, en 1938 reconoció al Gobierno de Burgos y, en 1939, manifestó su apoyo a Franco. ${ }^{29}$

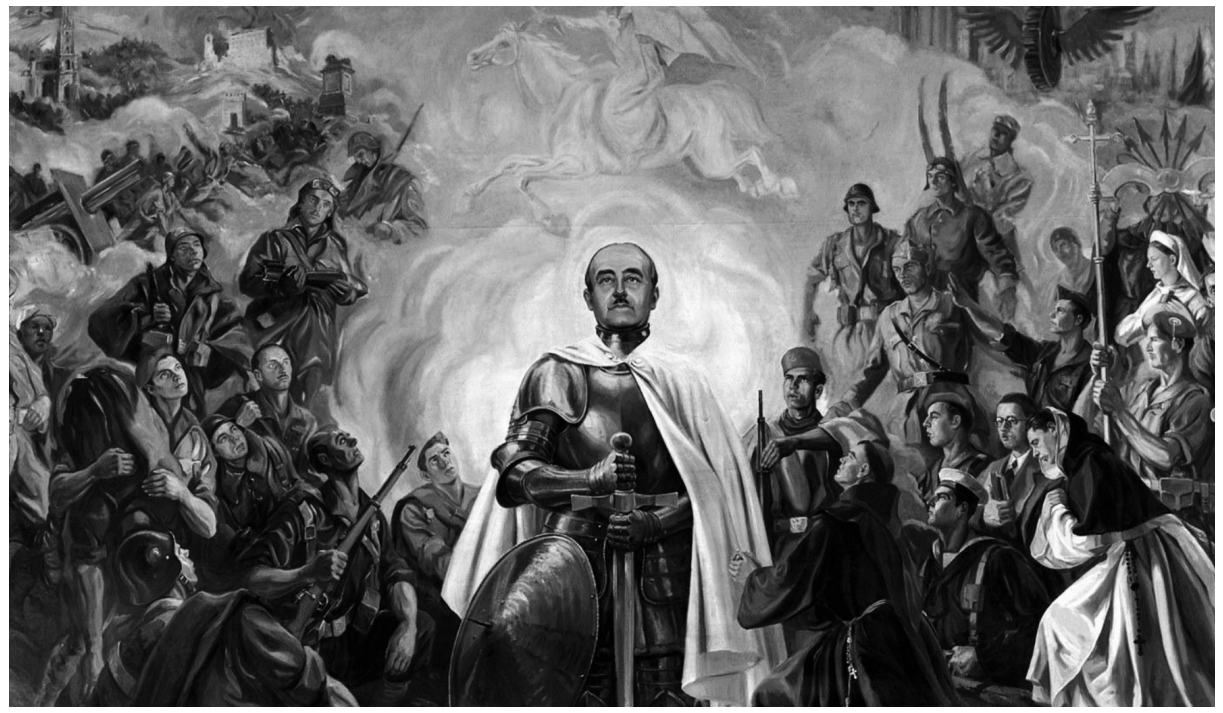

Ilustración 3. Franco como cruzado, 1946, mural de Arturo Reque para el Valle de los Caídos, hoy en el Instituto de Historia y Cultura Militar

${ }^{28}$ El 19 de marzo, Gomá comunicó en carta a Franco que Pío XII le enviaba su bendición. Paul Preston: Franco. Caudillo de España, Random House, 2017, p. 360 (ed. original Barcelona, Grijalbo Mondadori, 1993). El 3 de abril le escribe: "Dios que ha hallado en Vuecencia digno instrumento de sus planes providenciales sobre la Patria querida, nos ha concedido ver esta hora de triunfo", Por Dios y por España, 1936-1939, Constantino Bayle (ed.), Barcelona, 1940, pp. 537-540.

${ }^{29}$ El 1 de abril de 1939 Franco emite el parte de la victoria y, el mismo día, Pio XII le felicita por su "victoria católica": "hacemos votos para que ese queridísimo país, alcanzada la paz, emprenda con nuevo vigor sus antiguas cristianas tradiciones que tan grande lo hicieron". El 16 de abril, el Papa resalta la identidad entre Iglesia y Caudillo en una declaración por Radio Vaticano: "Con inmenso gozo nos dirigimos a vosotros, hijos queridísimos de la Católica España, para expresaros nuestra paterna congratulación por el don de la paz y de la victoria, con que Dios se ha dignado coronar el heroísmo cristiano de vuestra fe y caridad, probado en tantos y tan generosos sufrimientos". Hilari Raguer: La pólvora y el incienso. La Iglesia y la Guerra Civil española (1936-1939), Barcelona, Península, 2001, pp. 393-394; P. Preston: Franco..., p. 361. 


\section{La ceremonia de acción de gracias del 20 de mayo de 1939}

Tras la guerra civil hubo una serie de celebraciones de la victoria en todas las ciudades españolas y uno de sus actos más representativos fueron los espectaculares desfiles que tuvieron lugar en algunas de ellas. Estas celebraciones culminaron el 19 de mayo de 1939 con el desfile de Madrid. La prensa de todo el país (nacional y local) de los días 19 y 20 de mayo de 1939 describe prolíficamente todos los actos que se relatan a continuación, a menudo con textos idénticos, sin duda difundidos por la oficina de prensa franquista. La reconstrucción, más o menos detallada, de estas ceremonias puede también leerse en numerosos trabajos ${ }^{30}$.

Franco hizo su entrada triunfal en el desfile de Madrid-que duró cinco horas- en el que participaron 120.000 soldados, con una abrumadora presencia de tropas del Eje junto a las españolas. Las calles principales estaban engalanadas con los colores de los vencedores y al Paseo de la Castellana se le había cambiado el nombre por el de Avenida del Generalísimo Franco. En la tribuna de presidencia - una construcción efimera realizada para la ocasión en forma de arco triunfal-, Franco tenía en su podio el Víctor (ilustración 1) y, a los lados, numerosos pendones, recuerdo de famosas victorias de todas las épocas, traídos desde toda España que, junto con el escudo imperial,"reforzaban la idea de que Franco era el heredero de los grandes guerreros del más brillante pasado"31.

El día siguiente -20 de mayo- se celebró en la iglesia de Santa Bárbara (las Salesas Reales) una fastuosa ceremonia de acción de gracias oficiada por el Cardenal Gomá y diecinueve obispos, que investía a Franco como caudillo de España y representaba "como drama sacro la ideología de la guerra santa que acababa de concluir" 32 . La ceremonia fue organizada por Ramón Serrano Suñer, ministro del Interior, responsable de la Delegación Nacional de Prensa y Propaganda, y sus colaboradores ${ }^{33}$, todos ellos muy conscientes de la importancia de los símbolos, gestos y detalles ceremoniales, incluida la música ${ }^{34}$. El germanófilo Serrano Suñer, por ejemplo, era

${ }^{30}$ He realizado mi propia reconstrucción de los hechos con las crónicas periodísticas que cito, en especial ABC, 21-5-1936, pp. 4-9: "El caudillo impetra la ayuda de Dios para la forja del Imperio y es ungido con las palabras sacramentales de la Iglesia"; y P. Preston: Franco..., pp. 367 y ss.; Gorka Zamarreno: Movilizaciones de masas en el franquismo. Un espectáculo a la imagen de Francisco Franco, tesis doctoral, Universidad de Málaga, 2015, pp. 209 y ss., añade algunos detalles tomados del Diario de Navarra, 21-51939; y Z. Box: España, Año Cero... del diario Arriba de la misma fecha.

${ }^{31}$ G. Zamarreno: Movilizaciones..., p. 206.

32 Hilari Raguer: La pólvora..., p. 397.

${ }^{33}$ La Delegación Nacional de Prensa y Propaganda incluía la Dirección General de Propaganda, dirigida por Dionisio Ridruejo, y la Dirección General de Prensa, dirigida por José Antonio Giménez-Arnau.

${ }^{34} \mathrm{O}$ también el uso dramático del silencio, como sucedió en el traslado de los restos de José Antonio Primo de Rivera realizado en noviembre de 1939, véase Gemma Pérez Zalduondo: "Silence, Sound and Imaginaries: Soundscape and Musical Programming in the Funeral Ceremonies of José Antonio Primo de Rivera (1939)", Music and Spanish Civil War, Gemma Pérez Zalduondo, Iván Iglesias (eds.), Berna, Peter Lang (en prensa). 
perfecto conocedor de la obsesión nazi por el pasado de los pueblos germánicos ${ }^{35}$, de sus métodos de propaganda y de los espectaculares y multitudinarios desfiles, ceremonias y escenificaciones organizadas por el ministro de Ilustración Pública y Propaganda, Joseph Goebbels, en Alemania desde comienzos de los años treinta. También el cardenal Gomá había participado en enormes concentraciones de masas de gran repercusión mediática durante el Congreso Eucarístico Internacional celebrado en Buenos Aires en $1934^{36}$. En él, la música -y los espectáculos visuales- tuvieron gran importancia, encargándose la programación de la primera a una comisión formada por profesionales, pero presidida por el secretario del Arzobispo. En el congreso estaba muy presente por un lado "la España antirrepublicana, cuya idea fundacional se reencontraba en la de los Reyes Católicos; por otro, el Vaticano de los recientes pactos lateranenses y, en relación con ello, la admirada Italia mussoliniana" ${ }^{37}$.

La oficina de prensa del Gobierno franquista de Burgos comunicó con casi un mes de antelación a la prensa nacional e internacional que "la entrada del general Franco en Madrid seguirá el ritual observado cuando Alfonso VI, acompañado por el Cid, tomó Toledo en la Edad Media" 38 , mostrando la venerabilidad y magnificencia que se quiso dar a la ceremonia al comparar la toma de Toledo en 1085 con la victoria de Franco.

\footnotetext{
${ }^{35}$ En 1935 se había creado por dirigentes del Partido Nazi la Studiengesellschaft für Geistesurgeschichte "Deutsches Ahnenerbe" e.V. (Sociedad para el Estudio de la Prehistoria Cultural "Herencia Ancestral Alemana”, Sociedad Registrada) para realizar investigaciones en apoyo a su ideología demostrando, entre otras cosas, la supremacía aria, y relacionando esta raza con los godos para legitimar así los delitos derivados de esa supremacía, como la persecución étnica y cultural; véase al respecto, por ejemplo, Michael H. Kater: Das "Ahnenerbe" der SS 1935-1945. Ein Beitrag zur Kulturpolitik des Dritten Reiches. Múnich, Oldenbourg, 1997 (2. ${ }^{a}$ ed.). Desde 1939 varios miembros de la Ahnenerbe, entre ellos Heinrich Himmler, visitaron España en busca de reliquias visigodas y se llevaron a Alemania numerosas piezas de distintos yacimientos arqueológicos, como Castiltierra, presuntamente para ser restauradas, véase Isabel Arias Sánchez, Luis Javier Balmaseda Muncharaz (coords.): La necrópolis de época visigoda de Castiltierra (Segovia). Excavaciones dirigidas por E. Camps y J. M. ${ }^{a}$ de Navascués, 1932-1935. Materiales conservados en el Museo Arqueológico Nacional. Tomo I: Presentación de sepulturas y ajuares, Ministerio de Educación, Cultura y Deporte, 2015, pp. 40-41 (https://sede.educacion.gob.es/publiventa/descarga.action?f_codigo_agc=15031C, consulta 101-2020).

${ }^{36}$ Se cree que pudo haber hasta un millón de personas en las concentraciones de Buenos Aires; para valorar la cifra hay que saber que el país contaba entonces con ocho millones de habitantes. Rogelio Alaniz: "El Congreso Eucarístico Internacional de 1934 (I)", El Litoral, 19-3-2014; Idem (II), El Litoral, 26-3-2014.

${ }^{37}$ Omar Corrado: "Música, nacionalismo y avance hispano-católico en Buenos Aires, 1934", Música, Musicología y Colonialismo, Coriún Aharonián (coord.), Centro Nacional de Documentación Musical Lauro Ayestarán, Montevideo, 2011, pp. 249-271 (p. 270).

${ }^{38}$ Por ejemplo, The Times, 17, 18 y 25 de abril y 4 y 19 de mayo de 1939, citado en P. Preston: Franco..., p. 367.
} 
A las once menos cuarto de la mañana del 20 de mayo de 1939, Franco llegó a la iglesia de las Salesas Reales donde ya le esperaban todas las autoridades civiles, militares y religiosas y una gran multitud. Hay que resaltar el regio escenario, la teatral fachada de una iglesia que es el único panteón real situado dentro de la ciudad de Madrid (de Fernando VI y Bárbara de Braganza) -lo que de nuevo asocia a Franco con la realeza-, y en la que estaba presente todo el Gobierno, consejeros nacionales y miembros de la Junta Política, el Cardenal Gomá, Primado de España y Arzobispo de Toledo, tres arzobispos, dieciséis obispos, el cuerpo diplomático presidido por el nuncio de Su Santidad, el Arzobispo de Winnipeg (Canadá), el Vicario Apostólico del Urubamba (Perú) y otras muchas personalidades ${ }^{39}$. La muchedumbre que le había acompañado durante todo el recorrido no podía entrar en la iglesia, pero veía su espectacular fachada decorada "con tapices del siglo XVIII que representaban la conquista de Túnez" ${ }^{40}$ y escuchaba los sonidos que acompañaron la entrada, pues Franco subió la escalinata de la iglesia en un atronador paisaje sonoro "bajo 10.000 palmas enarboladas por niños" ${ }^{41}$, con el repicar de las campanas y el tronar de los cañones, mientras se cantaba a gritos el Cara al sol $^{42}$.

Es de resaltar que, a pesar de la difusión por parte de la oficina de prensa de la explicación de la ceremonia, cuando la prensa menciona determinados hechos espontáneos o fuera del programa, las informaciones varían de unas fuentes a otras pues, a pesar de la importancia que el régimen daba a este evento, ni el público estaba tan coordinado como a Serrano Suñer le hubiera gustado (véase nota 42), ni la prensa terminaba de entender el ritual que estaba explicando (véase nota 43).

Franco entró en la iglesia bajo palio - privilegio reservado al Santísimo Sacramento, papas y monarcas- portado por los miembros del Gobierno y a su entrada el órgano tocó el himno nacional. En la iglesia se encontraban varias reliquias simbólicas representando el nexo con el pasado, como el Cristo de Lepanto, laVirgen de Atocha, el Arca Santa con las reliquias de Don Pelayo, la linterna de la nao capitana de Juan de Austria en Lepanto, o las

${ }^{39}$ H. Raguer: La pólvora..., p. 397; Fr. Antonio Carrión, O. P.: "Señor: para tu gloria y de tu Iglesia", De Rebus Hispaniae, 21-7-1939, pp. 5-6.

${ }^{40}$ Azul, 21-5-1939, p. 3.

${ }^{41}$ A. Carrión: "Señor: para tu gloria...", p. 5.

${ }^{42}$ G. Zamarreno: Movilizaciones..., p. 210, señala que existen "divergencias en la descripción de los hechos dependiendo de la fuente consultada. Arriba y Diario de Navarra citan a los miembros de la Falange mientras que $A B C$ habla de 'Un coro improvisado de señoritas y niños cantó el Cara al sol y el señor Serrano Suñer lo acompañó"'. Añado otra divergencia más, narrada a sus compañeros por monjes de Silos presentes en la ceremonia: "ante el desajuste de la muchedumbre cantando el Cara al sol, el P. Emilio Santamaría, monje de Silos, muy voluminoso y de potente voz, fue alzado por sus compañeros a una pilastra de la entrada de la iglesia y, desde allí, gritando y con gestos, consiguió unir al coro". Comunicación del P. Norberto Núñez, bibliotecario de Silos, 24-5-2019. 
cadenas históricas de Navarra ganadas en la batalla de las Navas de Tolosa. Comenzó la ceremonia con el canto de unas antífonas de rito hispánico del siglo X del Antifonario de León, interpretadas por un coro de casi treinta monjes benedictinos del Monasterio de Silos apoyado por otro de dominicos de Salamanca ${ }^{43}$. A continuación, el cardenal Gomá entonó un Te Deum, pieza que se suele cantar desde la Edad Media en celebraciones de acción de gracias y ceremonias como canonizaciones, ordenaciones, la elección de un papa o coronaciones reales. Posteriormente tuvo lugar una misa pontifical y después - cita el periodista con gran detalle- "terminó la acción de gracias al Altísimo por la Victoria con las preces Al regreso del caudillo de la guerra, recogidas del Liber Ordinum, de la edición de Dom Férotin, del siglo VII" ${ }^{44}$. A continuación,

El caudillo con voz clara y sonora pronunció la siguiente oración:

Señor, acepta complacido el esfuerzo de este pueblo, siempre tuyo, que conmigo por tu nombre ha vencido con heroísmo al enemigo de la Verdad en este siglo.

Señor Dios, en cuya mano está todo derecho y todo poder, préstame tu asistencia para conducir este pueblo a la plena libertad del Imperio, para gloria tuya y de tu iglesia.

Señor, que todos los hombres conozcan que Jesús es el Cristo, el Hijo de Dios vivo ${ }^{45}$.

El dictador, cual rey cruzado, entregó al cardenal la espada de la victoria sobre los "infieles", y Gomá la bendijo solemnemente. La espada fue depositada en el altar mayor ante el Cristo de Lepanto. El cardenal derramó sobre el caudillo la siguiente bendición mientras era ungido:

El señor sea siempre contigo. El, de quien procede todo derecho y todo poder y bajo cuyo imperio están todas las cosas, te bendiga y con amorosa providencia siga protegiéndote, así como el pueblo cuyo régimen te ha sido confiado. Prenda de ello sea la bendición que te doy en el nombre del padre, del Hijo y del Espiritu Santo ${ }^{46}$.

Terminado el acto, Franco salió de la iglesia de nuevo bajo palio. A las doce y media hubo un vino de honor en el Banco de España para los jefes y oficiales participantes en el desfile ${ }^{47}$. Esa tarde Franco recibió en El Escorial simbó-

\footnotetext{
${ }^{43}$ ABC, 21-5-1939, p. 7: "la Schola cantorum de los benedictinos y el coro de los Dominicos de Silos entonan las antífonas mozárabes del siglo X recogidas en el Antiphonarium mozarabicum Legionense que se conserva en el Archivo de Silos". El periodista aporta datos muy precisos procedentes sin duda de la oficina de prensa franquista, como el nombre del antifonario, pero se confunde en otros detalles: los monjes de Silos son benedictinos, no dominicos, y el Antifonario de León está en León. Azul, 21-5-1939, p. 3: "un coro de Benedictinos del Monasterio de Silos y otro de Padres Dominicos entonaron una composición sacra del siglo XVIII". El dominico A. Carrión: "Señor: para tu gloria...", p. 6, aclara este dato: se trataba de los dominicos de Salamanca que se unieron al coro de Silos.

${ }^{44}$ ABC, 21-5-1939, p. 7. El Liber Ordinum es un manuscrito del siglo XI, pero en el programa dice, efectivamente, siglo VII, que es la época de la que procede el ritual prescrito, no el libro que lo contiene.

${ }^{45}$ ABC, 21-5-1939, p. 8 (Las negritas son mías).

${ }^{46} \mathrm{Ibid}$. (Las negritas son mías).

${ }^{47}$ Heraldo de Zamora, 22-5-1939, p. 1.
} 
licamente las llaves del monasterio entregadas por su rector, con el que oró brevemente ante las tumbas de "sus antecesores" Felipe II y Carlos I y, por último, se celebró una recepción en la Sala Capitular y jardines ${ }^{48}$.

La ceremonia de las Salesas estuvo llena de detalles plenos de simbología -algunos más obvios, otros extremadamente sutiles- que, como veremos ahora, asociaban a Franco con la realeza hispana, en especial con los reyes godos: la celebración en una iglesia real, el uso del palio, las referencias al Imperio y a las virtudes del rey (la Verdad) tomadas del Liber Iudiciorum ${ }^{49}$, los estandartes, joyas y reliquias traídos para la ocasión, el uso de piezas de la liturgia hispánica reservadas a los reyes y, sobre todo, la unción.

Para hacer partícipe al público de toda esta simbología, se explicó con detalle a través del programa de mano (ilustración 4) y de la prensa todo lo que estaba sucediendo y su significado. El programa de mano se había enviado previamente a todos los asistentes con la invitación para la ceremonia. En su cubierta posterior aparecía una imagen de la coronación de un rey y en la anterior el águila imperial. En el interior del programa estaban los textos en latín de las piezas que se interpretaron y su traducción al castellano, indicando con detalle de erudito las fuentes y ediciones de las que se habían tomado, ediciones precisamente realizadas por monjes de Silos. Esos textos fueron las "Antífonas en la recepción del caudillo" -tomadas del Antifonario de León (E-L 8)- y las "Oraciones de la vuelta del caudillo después de la guerra" - del Liber Ordinum de Silos (E-SI 4)- que, por su contenido, eran perfectos para lo que se celebraba: "Nos alegramos de vuestra llegada, porque hemos recibido un varón bueno y amable para que haya alegría en este lugar [...]. Hemos deseado ver vuestra llegada con la mayor alegría”. En la edición textual se hicieron pequeñas adaptaciones cambiando las rúbricas, pues las originales eran en E-L 8 "Antífonas para la recepción del rey cuando viene de lugares cercanos", y en E-SI 4 "Oraciones para cuando el rey vuelve con su ejército de la guerra".También se incluyó en el programa el nombre de Francisco Franco donde los manuscritos dejan lugar para el nombre del rey -indicando ille- y se cambiaron las palabras rex (rey) por dux (caudillo) y thronum (trono) por dominatum (dueño).

Todos los medios mencionan estos antiguos cantos hispánicos y publican la traducción de sus textos, resaltando la sanción religiosa del poder que con ella se le concedía a Franco. ¿A quién y por qué se le ocurrió la idea de usar estas ceremonias de los monarcas visigodos? Y por otra parte, ¿cómo es que el coro cantó piezas del rito hispánico si-como he recordado antes- las melodías de este rito no se conservan?

${ }^{48}$ El Progreso de Lugo, 21-5-1939, p. 1.

${ }^{49}$ El Liber Iudiciorum o Lex Visigothorum, es el corpus legal visigodo de ca. 654. En su exhortación al buen rey dice que debe poseer dos virtudes: la Justicia y la Verdad. El Fuero Juzgo "en latin y castellano, cotejado con los más antiguos y preciosos códices", Madrid, Ibarra, 1815. Primus Titulus, I et II: "Sicut enim sacerdos a sanctificando ita et rex a moderamine pie regendo vocatur [...] Regiae igitur virtutes praecipuae dua sunt: justita et veritas [...]". 
Ante la escasez de documentos sobre la preparación de este acto (correspondencia, actas de reuniones, etc.), no es fácil reconstruir las intenciones de los participantes en su diseño, ni el nombre y el papel de cada uno de ellos. Sin embargo, analizando el resultado -la construcción litúrgica del acto-, solo cabe llegar a una conclusión. La responsabilidad e idea de esta celebración tuvo que ser de la Delegación Nacional de Prensa y Propaganda y, en última instancia, del ministro Serrano Suñer, pero está claro que todos los detalles litúrgicos e históricos de la celebración son demasiado especializados para ser conocidos por los políticos, que fueron sin duda asesorados para el diseño de la ceremonia por expertos conocedores de estos rituales. Se da la circunstancia de que en 1939 -como ahoramuy pocas personas conocían la liturgia hispánica y entonces -no ahora- la mayor parte de ellas eran monjes del monasterio de Santo Domingo de Silos. Los monjes de Silos son mencionados por toda la prensa como intérpretes de las piezas musicales que acompañaron la ceremonia de acción de gracias, sin embargo, como explicaré a continuación, creo que tras esa escueta mención se encuentran los creadores del simbólico programa que pretende mostrar a Franco como "rey ungido" según antiguas ceremonias que ellos conocían muy bien por haber editado los dos manuscritos de las que se tomaron.

En 1928 los monjes de Silos habían publicado la edición de los textos del Antifonario de León ${ }^{50}$, un antifonario del siglo $\mathrm{X}^{51}$, el único conservado completo del rito hispánico. En el Antifonario se incluyen los Oficios de unción de los reyes entre los que se encuentran las antífonas seleccionadas para la ceremonia de las Salesas. La autoría de la edición es colectiva-firmada por "los monjes de Silos"- pero el prólogo lo firma su abad, el historiador y liturgista Luciano Serrano (1879-1944), quien fue el autor de la parte paleográfica del texto, para la que contó con la colaboración de Germán Prado (1891-1974) como liturgista, y de Casiano Rojo (1877-1931) como musicólogo ${ }^{52}$. El resto de piezas hispánicas cantadas en las Salesas fueron los oficios y oraciones para cuando el rey vuelve de la guerra, del Liber Ordinum de Silos, editadas en 1904 por Marius Férotin (1855-1914) -monje de Silos entre 1881 y $1892-{ }^{53}$. En Silos se encontraba también entonces Justo Pérez de Urbel (1895-1979), que desde 1938 era formador, guía espiritual y capellán de la Sección Femenina de la Falange. Serrano, Prado y Pérez de Urbel -Férotin y Rojo habían fallecido- estuvieron en la ceremonia de 1939 partici-

\footnotetext{
${ }^{50}$ Antiphonarium mozarabicum de la Catedral de León, PP. Benedictinos de Silos (eds.), León, 1928.

${ }^{51}$ Copiado en torno al año 960 en el Reino de León para el abad Ikila, del Monasterio de Santiago de León, véase Carmen Julia Gutiérrez: "Librum de auratum conspice pinctum. Sobre la datación y la procedencia del Antifonario de León”, Revista de Musicología, XLII, 1, 2020, pp. 19-76.

${ }^{52}$ Así lo indica en la necrológica de Germán Prado de Tomás Moral: "La obra litúrgica del padre Germán Prado OSB (1891-1974)", Ephemerides Liturgicae, 90, 1976, p. 215.

${ }^{53}$ Marius Férotin, OSB: Le Liber Ordinum en usage dans l'Église wisigothique et mozarabe d'Espagne du cinquième au onzième siècle, Monumenta Ecclesiae Liturgica, vol. 5, París, 1904.
} 
pando en la liturgia y en el coro, dirigido por Prado. Germán Prado era el director del coro de Silos desde 1931 y, por su conocimiento de la liturgia hispánica y competencia musical, que demuestran las numerosas obras sobre el tema que publicó desde $1926^{54}$, fue el encargado de la dirección de la parte litúrgico-musical de la ceremonia de 1939, como lo sería años después de otras ceremonias a las que me referiré más adelante ${ }^{55}$. Pérez de Urbel, por su parte, además de numerosos y breves artículos dedicados a santos hispánicos publicados desde su primera juventud, contaba en su ingente producción con algunas obras sobre liturgia hispánica también desde $1926^{56}$.
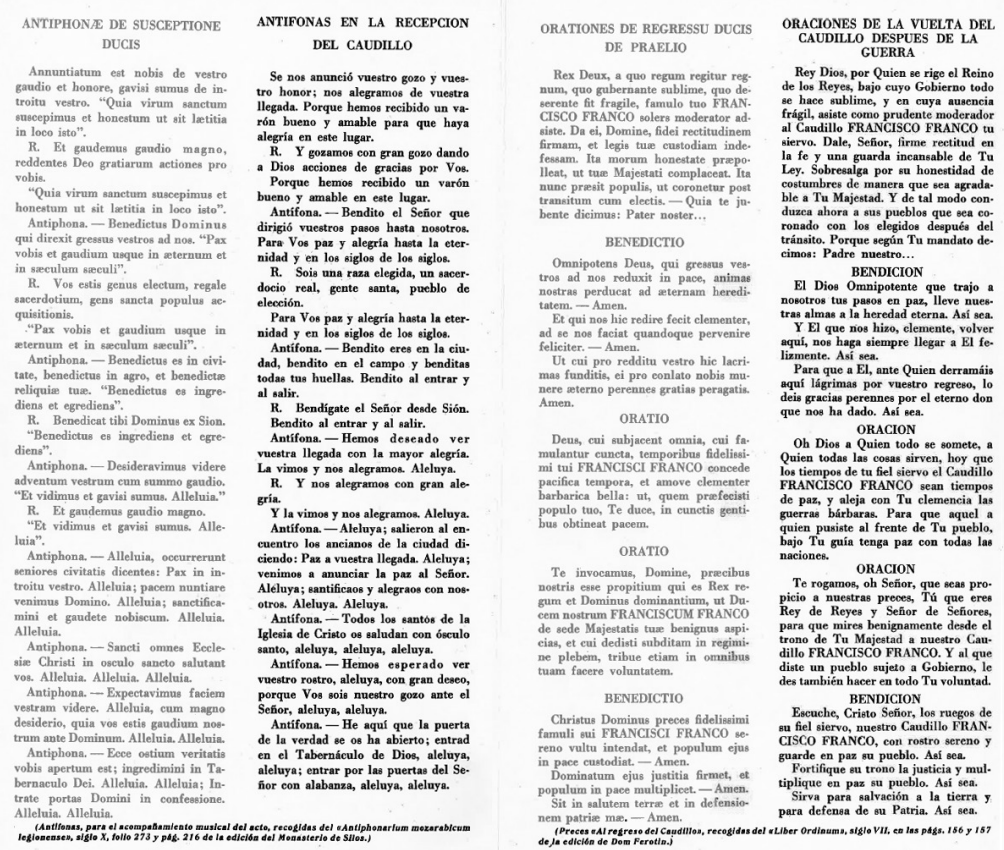

Ilustración 4. Programa de mano del acto de acción de gracias, cortesía del Archivo del Monasterio de Silos

${ }^{54}$ Germán Prado: Textos inéditos de la Liturgia mozárabe, Junta para Ampliación de Estudios e Investigaciones Científicas, Centro de Estudios Históricos, Madrid, 1926; -: Manual de Liturgia hispanovisigótica o mozárabe, Madrid, 1927; -: "Mozarabic Melodies", Speculum, 3, 1928, pp. 218-238; y sobre todo -: Historia y estado actual de la liturgia toledana con relación a la liturgia actual de la iglesia, trabajo premiado y editado por la Real Academia de Bellas Artes y Ciencias Históricas de Toledo, 1927, publicado después como Historia del rito mozárabe y toledano, Abadía de Silos, 1928, que fue la base de Casiano Rojo, Germán Prado: El canto mozárabe, Diputación Provincial de Barcelona, 1929.

${ }^{55}$ Consagración de la Cámara Santa, Oviedo, 1942; Milenario de Castilla, Covarrubias, 1943; y Centenario de la muerte de San Benito, Silos, 1956. T. Moral: "La obra litúrgica...", p. 214.

${ }^{56}$ Justo Pérez de Urbel: "Origen de los himnos mozárabes", Bulletin Hispanique, 18, 1926, pp. 5-21, 113-139, 209-245, 305-320; -: "La misa mozárabe", Revista Eclesiástica, 61, 1928, pp. 99-104, 147-155; -: Los monjes españoles en la Edad Media, Madrid, 1933-1934. 
Estos tres monjes encontraron una manera efectiva y con base histórica de resaltar el carácter de "elegido" del caudillo y legitimar su poder a través de la memoria visigoda y el rito hispánico que tan bien conocían. Serrano falleció en 1944, y Prado era un hombre modesto, recogido y dedicado al estudio, pero Pérez de Urbel alcanzó gran proyección por su influencia en el régimen. En 1948 se trasladó a Madrid como prior en el Monasterio de Montserrat -Prado también se trasladó con él y permaneció allí hasta su muerte-, y se convirtió en Consejero Nacional del Movimiento, censor, procurador en Cortes y, en 1958, primer abad del Valle de los Caídos.

\section{El ceremonial de unción de los reyes visigodos}

La ceremonia escogida para la acción de gracias de las Salesas fue, con toda intención, la de consagración y unción de los reyes visigodos, que el Antifonario de León denomina Ordinatione sive Natalicio regis porque, en efecto, el rey es ordenado y "nace" como tal con ella. Esta ceremonia ha sido estudiada desde múltiples aspectos por muchos investigadores, pues es una de las bases de la concepción política goda ${ }^{57}$. En estos estudios -que en los últimos años se centran sobre todo en la historia de las formas del poder, sus representaciones y símbolos- los historiadores explican la teoría política goda, intentan establecer si hubo o no coronación, cuándo y por qué se instauró el rito de la unción y quién fue el primer rey en ser ungido. Resumiendo al máximo la cuestión, diremos que la unción de reyes procede del Antiguo Testamento, cuando los sacerdotes sacralizaban a los reyes -como sucede con David o Salomón- y que los primeros monarcas occidentales en instaurar este rito fueron los visigodos. La unción real de la que conservamos un testimonio más antiguo es la de Wamba en 672, relatada por San Julián de Toledo ${ }^{58}$, y de ella se deduce que esa ceremonia era ya algo habitual. Algunos autores creen que puede

\footnotetext{
${ }^{57}$ Por solo citar algunos, véase Marc Reydellet: "La conception du souverain chez Isidore", Isidoriana, 1961, pp. 457-466; Claudio Sánchez Albornoz: "La 'Ordinatio principis' en la España goda y postvisigoda", Cuadernos de Historia de España, 35-36, 1962, pp. 5-36, José Orlandis: "El poder real y la sucesión al trono en la monarquía visigoda". Estudios Visigodos, III, 1962, pp. 1-123; Abilio Barbero: "El pensamiento político visigodo y las primeras unciones regias en la Europa medieval", Hispania: Revista Española de Historia, 115, 1970, pp. 245-326; P. D. King: Derecho y sociedad en el reino visigodo, Madrid, Alianza Editorial, 1981; Paola Manfredini: De Isidoro a Ildefonso. Teología política e politica eclesiástica na Hispania visigoda do séc. VII, Curitiba, 2004; Luis A. García Moreno: "Prosopography, Nomenclature, and Royal Succession in the Visigothic Kingdom of Toledo", Journal of Late Antiquity, 1, 1, 2008, pp. 142-156.

58 "Liber de Historia Galliae", Patrologiae Cursus Completus. Series Latina, Jacques-Paul Migne (ed.), t. XCVI, París, 1862, col. 763-766.
} 
retrotraerse a 632 -para Sisenando- ${ }^{59}, 621$-para ungir a Recaredo ${ }^{60}$ - o incluso a 580 -para Hermenegildo- ${ }^{61}$. De los reyes godos, con las migraciones de hispanos al norte tras el $711^{62}$, la ceremonia pasó a la corte carolingia en la consagración de Pipino en 751 y 754, y después a la anglosajona en $785^{63}$.

Los reyes germanos alcanzaban el poder como guerreros, con autoridad para proteger al pueblo y hacer justicia, y su acceso a la realeza combinaba la herencia de sangre, la sucesión y la elección ${ }^{64}$. Pero, como señala Rucquoi, la península ibérica, con su gran herencia romana, tenía una serie de características -antigua tradición urbana, un derecho civil escrito, una colección canónica y una larga historia de autonomía eclesiástica ${ }^{65}$ - que fundamentaron un poder real diferente al de los reinos del norte y que, además, dio lugar a la concepción de la doble naturaleza del rey cristiano como ser humano y divino ${ }^{66}$, pues la elección de los reyes godos fue definida por la Iglesia.

El carácter sagrado del rey godo ya se percibe a fines del sigloVI en Juan de Biclara $^{67}$, y es mucho más claro en el IV Concilio de Toledo (633) presidido por San Isidoro, cuya figura es fundamental en la construcción política goda. Los nobles y obispos godos, decidieron en aquel concilio apoyar al usurpador Sisenando en contra de un nuevo usurpador, e Isidoro plasmó en el canon

\footnotetext{
${ }^{59}$ C. Sánchez-Albornoz: "La ‘Ordinatio principis'...”, pp. 8-16.

${ }^{60}$ M. Férotin: Le Liber Ordinum..., col. 498; C. Sánchez Albornoz: "La ‘Ordinatio principis'...”, p. 16.

${ }^{61}$ Jorge Morín de Pablos, Rafael Barroso Cabrera: "Imagen soberana y unción regia en el reino visigodo de Toledo", Codex aquilarensis: Cuadernos de Investigación del Monasterio de Santa María la Real, 20, 2004, pp. 6-65.

${ }^{62}$ De la misma manera que el "renacimiento carolingio" se debe en gran medida a la llegada a la corte franca de estos clérigos hispanos, como sabemos al menos desde L'Europe héritière de l'Espagne wisigothique, Jacques Fontaine, Christine Pellistrandi (eds.), Madrid, Casa de Velázquez, 1992.

${ }^{63}$ C. Sanchez Albornoz: "La 'Ordinatio principis' ...”, p. 17.

${ }^{64}$ José María de Francisco Olmos: "El problema de la sucesión al trono en la monarquía visigoda: fuentes numismáticas, Anuario de historia del derecho español, 78-79, 2008-2009, p. 116

${ }^{65}$ Adeline Rucquoi: "De los reyes que no son taumaturgos: los fundamentos de la realeza en España", Relaciones. Estudios de Historia y Sociedad, El Colegio de Michoacán, México, XIII, 51, 1992, pp. 55-100.

${ }^{66}$ Doble naturaleza que estudia Ernst H. Kantorowicz: The King's Two Bodies. A Study in Mediaeval Political Theology, Princeton University Press, 1957 (trad. al español, 1985). Sin embargo, ni esta ni otras obras que se consideran fundamentales en la historia de las formas del poder y sus representaciones -en especial Marc Bloch: Les rois thaumaturges, París, Librairie Istra, 1924 (trad. al español, 1988); y Percy Ernst Schramm: Herrschaftszeichen und Staatssymbolik, 1956- tienen en cuenta las monarquías del Sur de Europa, a las que consideran regiones periféricas. Como Señala A. Rucquoi: "De los reyes...", pp. 57-58, el gran éxito de los propagandistas de los monarcas medievales de Francia, Inglaterra y el Imperio, consiste en que su superioridad -los poderes curativos estudiados por Bloch, por ejemplo- se hayan tomado como axioma y no como producto de sus servicios de propaganda.

${ }^{67}$ Según Rafael Barroso Cabrera, Jorge Morín de Pablos, Isabel Velázquez Soriano: "La imagen de la realeza en el reino visigodo de Toledo a través de la iconografía y la epigrafía", Zona Arqueológica, 11, 2008, pp. 488-508 (p. 501). Véase la Crónica en Pablo Álvarez Rubiano: "La Crónica de Juan Biclarense. Versión castellana y notas para su estudio", Analecta Sacra Tarraconensia, 16, 1943, pp. 7-44.
} 
LXXV una teoría política -la constitución visigoda, se podría decir- de pensamiento cristiano: "la última decisión de todos nosotros, los obispos, ha sido redactar en presencia de Dios, el último decreto conciliar, que fortalezca la situación de nuestros reyes y dé estabilidad al pueblo de los godos" ${ }^{68}$. Se decretó así el sistema de elección del rey -realizada por nobles ${ }^{69}$ y obispos- y la excomunión y condena a quien rompiera el juramento de fidelidad hacia él, atentara contra su vida o intentara usurpar el trono. El rey por su parte debía jurar que gobernaría con moderación, benevolencia, justicia y piedad, cualidad esta última que lo sometía a su vez a las leyes de la Iglesia.

Isidoro no describe ninguna ceremonia en el IV Concilio, pero dos pasajes de sus Etimologías se refieren a la unción real:"en la Antigua Ley, en la que solía ungirse a los elegidos para el sacerdocio y para el poder real, por lo cual Moisés ungió a Aarón" (Etymologiarum VI, 19, 51) y "del mismo modo que hoy día los reyes ostentan la insigne vestidura de la púrpura como símbolo de la dignidad regia, así entre ellos - los judíos- la unción con el sagrado crisma confería el nombre y la potestad de rey" (Etymologiarum VII, 2, 2) ${ }^{70}$. La coronación de Wamba en 672 muestra un ritual en el que la unción ya estaba perfectamente establecida (véase nota 58). De hecho, para la Iglesia, la unción es el ritual más significativo de la ceremonia, pues por ella el monarca adquiere un carácter sagrado y cuenta desde entonces - aunque solo mientras sea rey-, con una doble personalidad, humana y divina. Como dice Kantorowicz, es una persona geminada por el poder del sacramento ${ }^{71}$, por lo que la rebelión en su contra supone un sacrilegio "porque no solo se comete contra ellos una violación de lo pactado, sino también contra Dios, en el nombre del cual se hizo la dicha promesa" 72 . Con la unción, el rey pasa a ejercer la misión divina que tiene encomendada: conducir al pueblo cristiano, darle leyes y poner los medios para acatar la palabra divina.Tras ella, como resume Bango, puede decir:"después del Dios del cielo, el que manda, soy yo"73. Sin embargo, puesto que cualquier usurpador que triunfase en su empeño era ungido y por tanto legitimado, la unción -como el juramento de fidelidad-se redujo a un mero símbolo ${ }^{74}$.

\footnotetext{
${ }^{68}$ Concilios visigóticos e hispano-romanos, José Vives (ed.), Barcelona-Madrid, CSIC, Instituto Enrique Flórez, 1963, pp. 217-221.

${ }^{69}$ Los nobles se oponían a la sucesión dinástica a no ser que la dinastía fuera la suya.

${ }^{70}$ San Isidoro de Sevilla, Etimologías, 2 vols, José Oroz Reta, Manuel Marcos Casquero (eds.), Madrid, BAC, 1982, pp. 617, 633, citado en Isidro Bango: "Hunctus Rex. El imaginario de la unción de los reyes en la España de los siglos VI al XI", Cuadernos de Prehistoria y Arqueología, 37-38, 2011-2012, p. 750.

${ }^{71}$ Ernst H. Kantorowicz: Los dos cuerpos del rey. Un estudio de teología política medieval, Madrid, Alianza, 1985, p. 32: "Debemos por tanto reconocer en el rey una persona geminada, una proveniente de la naturaleza geminada, y otra de la gracia. Una por la cual, en virtud de la naturaleza, se asemejaba a los hombres; y otra por la cual, en virtud de la eminencia de la deificación y por el poder del sacramento superaba a todos los demás".

${ }^{72}$ Concilios visigóticos..., pp. 217-221.

${ }^{73}$ I. Bango: "Hunctus Rex...", p. 750.

${ }^{74}$ R. Barroso Cabrera, J. Morín de Pablos, I. Velázquez Soriano: “La imagen..., p. 503.
} 
La ceremonia de unción y coronación de un rey visigodo no se conserva completa en ningún manuscrito medieval, pero ha sido reconstruida por algunos investigadores ${ }^{75}$ tomando las piezas litúrgico-musicales y lecturas de determinados libros y deduciendo el ceremonial de los textos de las propias piezas o de descripciones históricas, aunque no sabemos desde cuándo se realizaban determinadas acciones. He aquí la reconstrucción de Sánchez Albornoz -las notas al pie y las negritas son mías-, que coincide casi por completo con la ceremonia de las Salesas (véase tabla 1):

Elegido el nuevo rey conforme a derecho, designado para regir el reino por voluntad del monarca reinante, en trance de muerte o previéndola cercana, o triunfante el golpe de estado o la lucha armada que había llevado al regimiento del país a un nuevo príncipe, recibía este el poder real mediante ceremonias que nos son mal conocidas, que acaso consistían en la coronación y en la ocupación del solio regio; y en el mismo acto o días después para que se realizara en la sede regia de Toledo y en domingo, tenían lugar el juramento y la unción. Cubierto con las regias vestiduras purpúreas, el nuevo soberano se trasladaba a la iglesia palatina de San Pedro y San Pablo ${ }^{76}$. En ella, ante el altar, juraba fidelidad al pueblo ${ }^{77}$; escuchaba quizás una exhortatio en la que le eran recordados sus deberes ${ }^{78}$; arrodillado delante del metropolitano era ungido con el óleo santo en la cabeza y en las manos ${ }^{79}$ y terminaba la ceremonia con la misa de ritual para ocasiones tan solemnes ${ }^{80}$.

Bango $^{81}$ también reconstruye la ceremonia siguiendo el contenido de los textos de las piezas litúrgicas y añade que la unción se haría sobre la coronilla del monarca y seguramente sobre otras partes del cuerpo. Una vez ungido, sería vestido con la stola regalis y recibiría la bendición del oficiante. A continuación, se procedería a la imposición de la corona y, por último, se produciría la manifestación mayestática del monarca, luciendo la corona y el indumento regio.

\footnotetext{
${ }^{75}$ Como M. Férotin: Le Liber Ordinum..., col. 499-505; C. Sánchez Albornoz: "La 'Ordinatio principis'...", e I. Bango: "Hunctus Rex...".

${ }^{76}$ Iglesia palatina de Toledo situada en "suburbio toletano" según el canon IV del Concilio XII de Toledo, reunido en ella en 681, M. Férotin: Le Liber Ordinum..., col. 150-151.

${ }^{77}$ No se conserva la fórmula del juramento.

${ }^{78}$ Quizá la Via regia, M. Férotin: Le Liber Ordinum..., col. 500-503.

${ }^{79}$ Acompañaba el obispo este gesto de una Benedictio o plegaria solemne, por la cual pedía para el rey las bendiciones celestes, M. Férotin: Le Liber Ordinum..., col. 501.

${ }^{80}$ C. Sánchez Albornoz: "La ‘Ordinatio principis'..." pp. 16, 17 realiza la reconstrucción por E.L 8 y E-SI 4. Las negritas son mías.

${ }^{81}$ I. Bango: "Hunctus rex...", pp. 755-756.
} 
Tabla 1. Similitud entre la ceremonia de unción de reyes visigoda y la de 1939

\begin{tabular}{|l|l|}
\hline Ceremonia de unción de reyes visigodos & Ceremonia de franco de 1939 \\
\hline - Celebrada en sede regia & - Celebrada en las Salesas Reales \\
- Ereferiblemente en domingo & - Fue un rábado prestará juramento \\
- El rey se arrodillará & - Franco rezó una oración \\
- El rey será ungido & - Franco se arrodilló \\
- El obispo rezará una bendición & - Franco fue ungido \\
\hline
\end{tabular}

La miniatura del Oficio de Ordenación de Reyes del Antifonario de León representa a un rey ungido por dos obispos, viste ropa talar con largo manto y se arrodilla sobre un gran cojín, un obispo le bendice y otro alza sobre él el cuerno con el óleo. La Historia Silense narra la coronación de Ordoño II con doce obispos; Franco tuvo veinte y la foto de prensa lo muestra en uniforme de gala y arrodillado ante el obispo que lo va a ungir (ilustración 5).
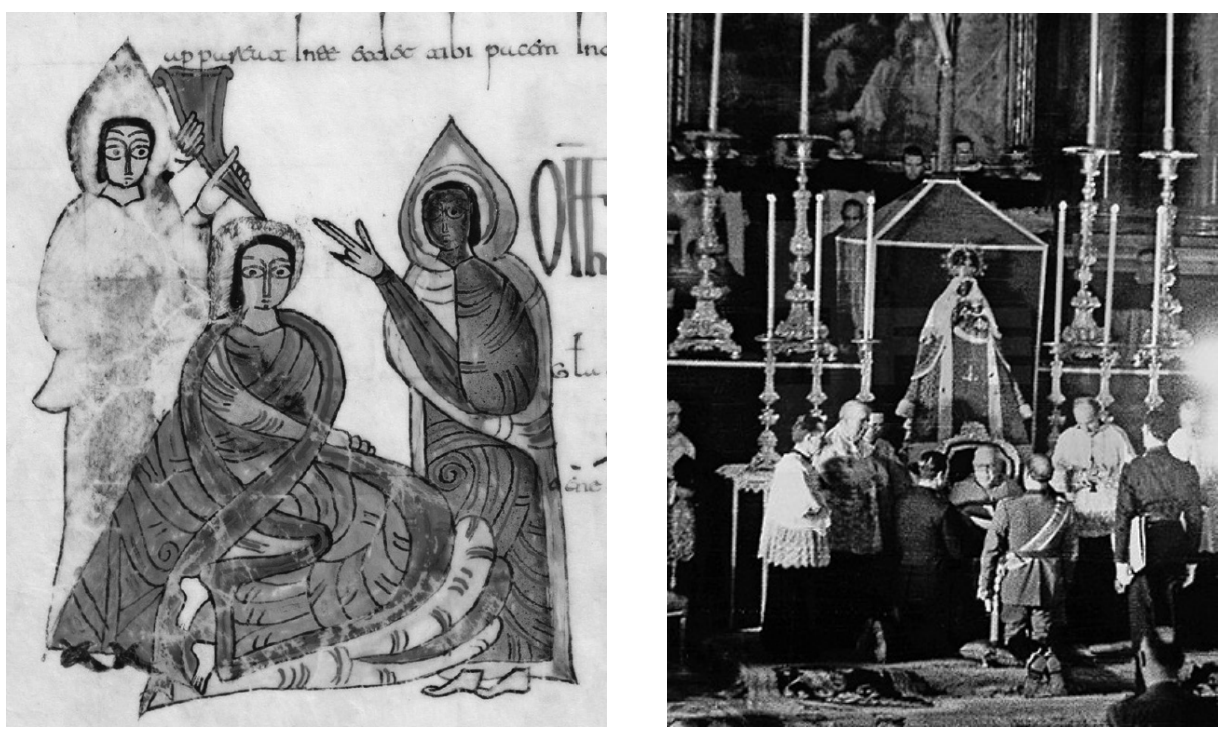

Ilustración 5. Miniatura del oficio de coronación del rey, E-L 8,f.271v y unción de Franco en las Salesas (Agencia Efe)

\section{Los reyes ungidos}

Una cuestión de interés para los historiadores ha sido discernir qué reyes cristianos fueron ungidos en los sucesivos reinos medievales hispanos. Sus conclusiones son interesantes para el tema que nos ocupa. El linaje real visigodo se extinguió en 531 y comenzó entonces un período marcado por continuas 
luchas por el poder.Varios reyes fueron generales elegidos por el ejército -Teudis en 531, Teudiselo en 548- o por la nobleza -Agila I en 555, Liuva I en 568-, hasta llegar a Leovigildo, hermano de Liuva y asociado al trono de este en 570. Tras Leovigildo, otros reyes usaron también la táctica de asociar a sus hijos al trono para garantizar la sucesión, lo cual -por lo general- funcionó bien, aunque hubo alguna deposición -Witérico- o asesinato -Gundemaro-. Las noticias sobre unciones visigodas son poco concretas e irregulares, y por ello solo tenemos la seguridad de que se produjeran algunas bien documentadas, mientras que para otras hay dudas, pero sabemos que, al menos desde 621, los reyes ungidos son, precisamente, los usurpadores o los elegidos por la nobleza, es decir, los que necesitan la ratificación sagrada porque no son hijos legítimos del rey anterior. En la tabla 2 se ve el listado de reyes visigodos cristianos indicando cuáles fueron ungidos y su modo de acceso al trono. En caso de duda sobre su unción se explica quién la propone en una nota al pie.

Tabla 2. Reyes visigodos cristianos y sus unciones

\begin{tabular}{|c|c|c|c|}
\hline \multicolumn{4}{|c|}{ REINO DE TOLEDO } \\
\hline Ungido & Reyes visigodos & Acceso al trono & Reinado \\
\hline & Recaredo I & Hijo de Leovigildo & $586-601$ \\
\hline & Liuva II & Hijo de Recaredo I & $601-603$ \\
\hline & Witérico & Derrocó a Liuva II & $603-610$ \\
\hline & Gundemaro & Asesina a Witérico & $610-612$ \\
\hline & Sisebuto & Elegido por la nobleza & $612-621$ \\
\hline $\mathrm{Si}_{1}^{82}$ & Recaredo II & Hijo de Sisebuto & 621 \\
\hline $\mathrm{Si}^{83}$ & Suintila & Elegido por la nobleza & $621-631$ \\
\hline Sí & Sisenando & Derroca a Suintila & $631-636$ \\
\hline \multirow[t]{2}{*}{ Sí } & Chintila & Elegido por la nobleza & $636-639$ \\
\hline & Tulga & Hijo de Chintila & $639-642$ \\
\hline \multirow[t]{2}{*}{$\mathrm{Si}^{84}$} & Chindasvinto & Usurpa el trono a Tulga & $642-653$ \\
\hline & Recesvinto & Hijo de Chindasvinto & $649-672$ \\
\hline Sí & Wamba & Elegido por la nobleza & $672-680$ \\
\hline Sí & Ervigio & Elegido por Wamba como su sucesor & $680-687$ \\
\hline Sí & Égica & Yerno de Ervigio & $687-702$ \\
\hline Sí & Witiza & Hijo de la esposa de Égica & $700-710$ \\
\hline Sí & Rodrigo & Usurpa el trono & $710-711$ \\
\hline
\end{tabular}

\footnotetext{
${ }^{82}$ C. Sánchez Albornoz: "La 'Ordinatio principis'...”, p. 16.

${ }^{83}$ I. Bango: "Hunctus Rex...", pp. 750, 753.

84 "Leges Visigothorum", Karl Zeumer (ed.), Monumenta Germaniae Historia, Leges, I, Leipzig, 1902, p. 460, nota 4, citado en C. Sánchez Albornoz: "La 'Ordinatio principis'...”, p. 23.
} 
En la monarquía asturiana los reyes fueron elegidos entre la nobleza, pero no se mencionan unciones hasta el segundo reinado de Alfonso II ${ }^{85}$ en 791 (tabla 3), cuando recuperó el trono que le había usurpado su tío Mauregato. La siguiente unción asturiana es la de Alfonso III, hijo y asociado al trono de Ordoño I, a quien le disputó la corona Fruela, conde de Lugo. Precisamente con Alfonso II se había creado el programa político neovisigótico narrado en la Crónica de Alfonso III, del que he hablado antes, que fundamenta y legitima la monarquía asturiana recreando en Oviedo el goticismo y el aparato representativo de Toledo y que señala a Alfonso II como ungido ${ }^{86}$. Así, los dos Alfonsos que crean el programa goticista son los únicos reyes asturianos probablemente ungidos. Ambos, también, llegaron al trono tras disputas dinásticas.

Tabla 3. Reyes de Asturias y sus unciones

\begin{tabular}{|c|c|c|c|}
\hline \multicolumn{4}{|c|}{ REINO DE ASTURIAS } \\
\hline Ungido & Reyes de Asturias & Acceso al trono & Reinado \\
\hline & Pelayo & ¿?-737 & $718-737$ \\
\hline & Favila o Fáfila & Elegido, hijo de Pelayo & $737-739$ \\
\hline & Alfonso I el Católico & Elegido, cuñado de Favila & $739-757$ \\
\hline & Fruela I & Elegido, hijo de Alfonso I & $757-768$ \\
\hline & Aurelio & Elegido, primo de Fruela I & $768-774$ \\
\hline & Silo & Elegido, yerno de Alfonso I & $774-783$ \\
\hline & Alfonso II el Casto & Elegido, hijo de Fruela I & 783 \\
\hline & Mauregato & Elegido en oposición a Alfonso II (hijo de Alfonso I) & 783-789 \\
\hline & Bermudo I el Diácono & Elegido, hermano de Aurelio & $789-791$ \\
\hline $\mathrm{Si}^{87}$ & Alfonso II el Casto & Elegido, hijo de Fruela I & $791-842$ \\
\hline & Nepociano & Usurpador & 842 \\
\hline & Ramiro I & Designado por Alfonso II, hijo de Bermudo I & $842-850$ \\
\hline & Ordoño I & Hijo de Ramiro I & $850-866$ \\
\hline $\mathrm{Si}^{88}$ & Alfonso III el Magno & Hijo de Ordoño I & $866-910$ \\
\hline & Fruela II & Hijo de Alfonso III, rey de Asturias & $910-925$ \\
\hline
\end{tabular}

${ }^{85}$ C. Sánchez Albornoz: "La 'Ordinatio principis'...", p. 20, dice que la unción de Alfonso II muestra que se mantenía el ritual visigodo, quizá llevado al norte por clérigos rodriguistas que apoyarían a Pelayo, huidos tras 711 .

${ }^{86}$ M. Férotin: Le Liber Ordinum..., p. 505. Lo repite Isidro Bango: "Hunctus Rex...”, p. 753.

87 “Crónica de Alfonso III", Crónicas Asturianas, p. 138.

${ }^{88}$ Según la Historia Silense, Justo Pérez de Urbel, Atilano González Ruíz Zorrilla (eds.), Madrid, 1959. 
Algunos de los reyes leoneses también fueron ungidos (tabla 4). Ordoño II, como narra la Historia Legionense (antes Silense) ${ }^{89}$, fue aclamado por todos los obispos, abades y nobles de España reunidos, que le impusieron la diadema, tras lo cual fue ungido por doce obispos en el solio real, en León. Su hijo Ramiro II también fue ungido al alcanzar el trono tras una disputa dinástica en la que hubo tres reyes entre él y su padre ${ }^{90}$. Ramiro III, también con dificultades para llegar al trono, fue el siguiente, y tras él, todos sus descendientes. Después, solo los iniciadores de nuevas dinastías, Fernando I -también muy aficionado a ceremoniales góticos ${ }^{91}$ y AlfonsoVII, serán ungidos ${ }^{92}$. La ausencia de unciones posteriores no impide que se considere a los monarcas castellanos como ta ${ }^{93}$, sino que muestra la fortaleza de la institución, que no necesita fórmulas religiosas que la validen ${ }^{94}$.

\section{Las fuentes medievales de la ceremonia de unción de reyes y sus melodías}

Tabla 4. Reyes de León hasta la unión del reino con el de Castilla y sus unciones

\begin{tabular}{|c|c|c|c|}
\hline \multicolumn{4}{|c|}{ REINO DE LEÓN } \\
\hline Ungido & Reyes de León & Acceso al trono & Reinado \\
\hline & García I & Hijo de Alfonso III el Magno, rey de León & $910-914$ \\
\hline \multirow[t]{3}{*}{$\mathrm{Si}^{95}$} & Ordoño II & Hermano de García, entre 910-914 rey de Galicia & $914-924$ \\
\hline & Fruela II & Hijo de Alfonso III, rey de Asturias, usurpa el trono & $924-925$ \\
\hline & Alfonso Froilaz & Hijo de Fruela II & $925-926$ \\
\hline $\mathrm{S}_{1}^{96}$ & Alfonso IV el Monje & Hijo de Ordoño II, derroca a Alfonso Froilaz & $926-931$ \\
\hline Sí & Ramiro II el Grande & Hijo de Ordoño II, elegido por su hermano Alfonso IV & $931-951$ \\
\hline $\mathrm{S}_{1}^{97}$ & Ordoño III & Hijo de Ramiro II & $951-956$ \\
\hline
\end{tabular}

${ }^{89}$ Historia Silense, J. Pérez de Urbel, A. González Ruiz Zorrilla (eds.), p. 155.

${ }^{90}$ Crónicas Asturianas, Juan Gil Fernández, José Luis Moralejo, Juan I. Ruiz de la Peña (eds.), Oviedo, Servicio de Publicaciones de la Universidad de Oviedo, 1985, p. 246.

${ }^{91}$ Como recuerda M. Férotin: Le Liber Ordinum..., pp. 503-504, esta unción está bien documentada en el Libro de Horas de Fernando I (E-SC 696): Ordinatio Silense: Era MLXXVI, X kalendas IULII, consecratus [est] Dominus Fernandus in ecclesia beatae Mariae Legionensis, et unctus in regem a uenerande memorie Seruando eiusdem ecclesie catholico episcopo, Historia Silense, J. Pérez de Urbel, A. González Ruiz Zorrilla (eds.). No sabemos qué ceremonial siguen ni esta ni otras ordenaciones posteriores.

${ }^{92}$ En 1111 tiene lugar la ceremonia de unción del príncipe Alfonso, hijo de Urraca, en la catedral compostelana oficiada por Gelmírez. Historia Compostelana, Emma Falque Rey (ed.), Madrid, Akal, 1995, Lib. I. cap. LXVI, p.174. Tras este, todos los ceremoniales de coronación hispanos, hasta el siglo XV mantienen el mismo esquema: unción y entrega de las principales insignias reales (trono, espada, cetro, corona y túnica), con pequeñas variantes. La última unción documentada es la de Alfonso XI en 1332.

${ }^{93}$ José Manuel Nieto Soria: Ceremonias de la realeza. Propaganda y legitimación en la Castilla Trastámara, Madrid, Nerea, 1993, p. 41.

${ }^{94}$ José Manuel Nieto Soria: "Imágenes religiosas del rey", En la España Medieval, 9, 1986, pp. 713-714.

${ }_{95}$ Claudio Sánchez Albornoz: "El anónimo continuador de Alfonso III", Spiritus, Mendoza, 1942, pp. $23-29$.

${ }^{96}$ Justo Pérez de Urbel: Sampiro, su crónica, y la monarquía leonesa en el siglo X, Madrid, CSIC, 1952, p. 320. 


\begin{tabular}{|c|c|c|c|}
\hline \multicolumn{4}{|c|}{ REINO DE LEÓN } \\
\hline Ungido & Reyes de León & Acceso al trono & Reinado \\
\hline & Sancho I el Craso & Hijo de Ramiro II, opuesto a su hermanastro Ordoño III & $956-958$ \\
\hline & Ordoño IV el Malo & Hijo de Alfonso IV, usurpa el trono a su primo Sancho I & $958-960$ \\
\hline & Sancho I el Craso & Hijo de Ramiro II & $960-966$ \\
\hline Sí & Ramiro III & Hijo de Sancho I & $966-985$ \\
\hline $\mathrm{Si}^{98}$ & Bermudo II el Gotoso & Hijo de Ordoño III, en oposición a su primo Ramiro III & $985-999$ \\
\hline \multirow[t]{2}{*}{ Sí } & Alfonso V el Noble & Hijo de Bermudo II & $999-1028$ \\
\hline & Bermudo III el Mozo & Hijo de Alfonso V & $1028-1037$ \\
\hline \multirow[t]{5}{*}{ Sí } & Fernando I el Magno & derrotó y mató a su cuñado Bermudo III el Mozo & $1037-1065$ \\
\hline & Alfonso VI el Bravo & Hijo de Fernando I el Magno & $1065-1072$ \\
\hline & Sancho II el Fuerte & Usurpó el trono de León a su hermano Alfonso & 1072 \\
\hline & Alfonso VI el Bravo & Hijo de Fernando I el Magno & $1072-1109$ \\
\hline & Urraca I & Hija de Alfonso VI el Bravo & $1109-1126$ \\
\hline \multirow[t]{3}{*}{ Sí } & Alfonso VII el Emperador & Hijo de Urraca I & $1126-1157$ \\
\hline & Fernando II & Hijo de Alfonso VII el Emperador & $1157-1188$ \\
\hline & Alfonso IX & Hijo de Fernando II & $1188-1230$ \\
\hline
\end{tabular}

Conocemos los ritos dedicados a los reyes visigodos por varios manuscritos en los que se conservan, parcialmente al menos, sus textos. No tenemos libellus ceremonial ni rúbricas, lo que impide conocer con exactitud el desarrollo de la ceremonia. Estos son los libros ${ }^{99}$ :

\section{Antiphonarium E-L 8, ff. 271v-273r (ed. Benedictinos de Silos ${ }^{100}$, p. 216 y ss.)}

Officium in ordinatione sive natalicio regis, f. $271 \mathrm{v}$

Ad vesperum, f. $271 \mathrm{v}$

Ad Matutinum, f. 272r

Ad missam, f. $272 \mathrm{v}$

Ad Pugnam, f. 273r

Antiphonae de susceptione regis quando de vicina loca revertitur, f. $273 \mathrm{r}$

Liber commicus F-Pn 2171 f. 398-400 (ed. Morin ${ }^{101}$, pp. 301-303)

Lecturas del Antiguo y Nuevo Testamento para las ceremonias (Lectio de ordinatione regis) ${ }^{102}$

\footnotetext{
${ }^{97}$ Ibid., p. 332.

${ }^{98}$ Ibid., p. 342.

99 Sigo para esta ordenación sobre todo a M. Férotin: Le Liber Ordinum..., col. 499-503.

${ }^{100}$ Antiphonarium mozarabicum...

${ }^{101}$ Germain Morin, OSB: Liber comicus; sive, Lectionarius missae quo Toletana Ecclesia ante annos mille et ducentos utebatur, Brujas, Desclée de Brouwer et. soc., 1893.

${ }^{102}$ Reconstruidas por Serrano en Antiphonarium mozarabicum..., p. xxii. Según M. Férotin: Le Liber Ordinum..., col. 502, estas lecturas parecen indicar que había una misa para esta circunstancia.
} 
Liber ordinum, E-SI 4 ff. 107r-111v (ed. Ferotin ${ }^{103}$, col. 149-156)

Ritus pro rege observandus

Ordo quando rex cum exercitu ad prelium egreditur, $\mathrm{f} .107 \mathrm{r}$

Orationes de regressu regis, $\mathrm{f} .110 \mathrm{r}$

Oratio de susceptio regis quando de vicino regreditur, $\mathrm{f} .111 \mathrm{v}$

Breviarium E-Mn 10001, f. 100r y Breviarium GB-Lbl 30851, f. 158v

Himno para la ordenación del rey Inclite Rex magne regum (ed. Blume ${ }^{104}, \mathrm{n}^{\circ}{ }^{\mathrm{o}} 193$ )

\section{Actas conciliares}

Exhortación a los reyes en su consagración: Via regia uel exhortatio ad principem ${ }^{105}$ Texto del Ordo de celebrando concilio que parece reproducir las palabras del obispo en la Ordinatione regis ${ }^{106}$.

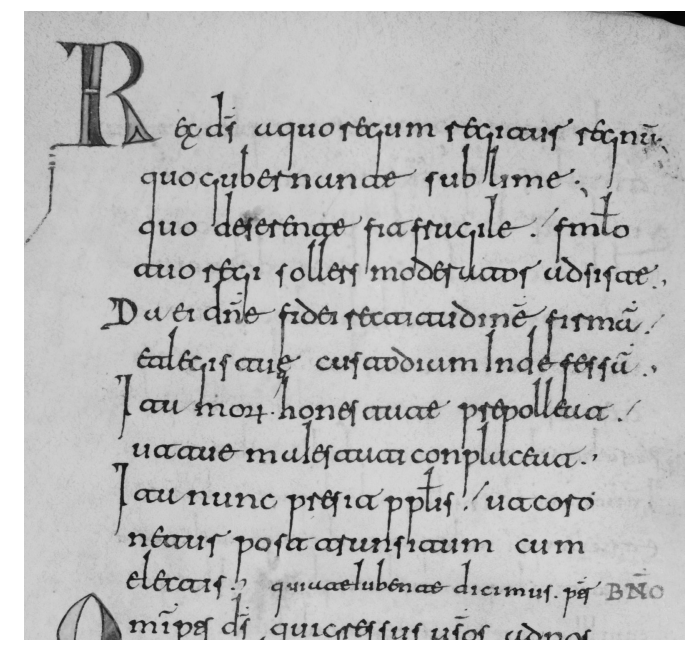

Ilustración 6. Liber Ordinum de Silos (E-SI 4,f. 111v):

Oratio de Susceptio regis quando de vicino regreditur, sin música

Si las fuentes permiten reconstruir los textos de la ceremonia, no sucede lo mismo con la música: las casi tres mil melodías del rito hispánico están notadas en un sistema muy rico y elaborado, pero que no permite conocer la altura de los sonidos representados. Solo conocemos la melodía de veintiún piezas transcritas por Rojo y Prado en 1929107; otras seis recuperadas

\footnotetext{
${ }^{103}$ Para las oraciones, y tiene además el Ordo pro solo rege.

${ }^{104}$ Clemens Blume: Hymnodia Gotica. Die Mozarabischen Hymnen des alt-spanischen Ritus, Analecta Hymnica Medii Aevi, vol. 27, Leipzig, O.R. Reisland, 1897.

${ }^{105}$ Discurso que aparece en la mayor parte de las colecciones conciliares como exhortación a los reyes visigodos en su consagración, resumen de sus deberes. Viene del Liber Iudiciorum, ca. 654, véase nota 44.

${ }^{106}$ M. Férotin: Le Liber Ordinum..., col. 503.

${ }^{107}$ E-Mah 56 y E-S 4, C. Rojo, G. Prado: El canto mozárabe..., pp. 73-78.
} 
por Carmen Rodríguez Suso ${ }^{108}$; y alguna otra pieza aislada ${ }^{109}$. Por supuesto, ninguna de ellas pertenece a la ceremonia de unción de reyes.

¿Qué melodías cantaron entonces los monjes de Silos en la ceremonia? Recordemos que escogieron dos grupos de piezas: unas oraciones y bendiciones del Liber Ordinum de Silos y unas antífonas del Antifonario de León. Las oraciones y bendiciones, como es habitual, no tienen música en el original (ilustración 6), pues se cantilaban según esquemas melódicos preestablecidos. El coro de Silos así lo debió hacer en las Salesas, ya que varios periódicos indican que "se cantaron". Para ello escogerían probablemente un tono tomado de los Cantorales de Cisneros, pues ese es el mismo procedimiento que usó Prado en otra reconstrucción posterior que sí conocemos, como señalaré después.

Otra cuestión es cómo cantaron las antífonas, que sí llevan una melodía propia. De todo el oficio de reyes no se escogieron las Vísperas, Maitines o Misa, con piezas mucho más largas y elaboradas, sino precisamente esas ocho antífonas, ninguna de las cuales tiene música en los versículos (ilustración 7), y solo cuatro la tienen en la antífona, aunque su notación adiastemática impide conocer sus melodías. No se han localizado fuentes directas de la música con las que las cantaron ${ }^{110}$, pero con toda seguridad los monjes de Silos tuvieron que escribir una melodía para esas piezas, pues el original no la tiene.

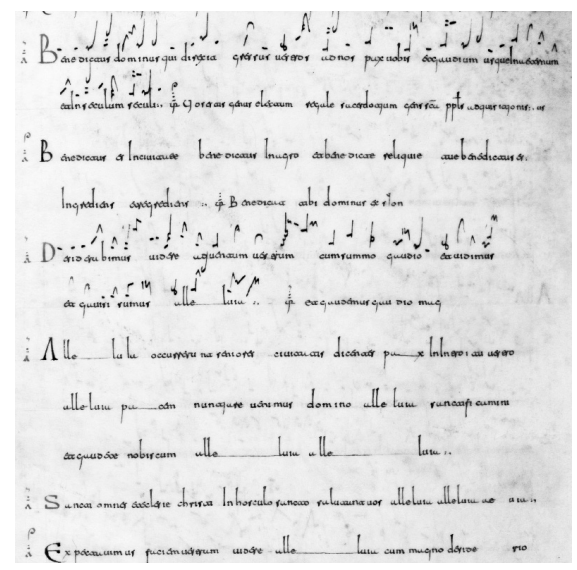

Ilustración 7. Antifonario de León (E-L8, 273v): Antiphonae de susceptione regis quando de vicina loca revertitur. Se ven cinco antifonas, de las que solo una tiene parcialmente música

${ }^{108}$ Carmen Rodríguez Suso: "L'évolution modale dans les antiennes de l'ordo wisigothique pour la consécration de l'autel”, Etudes Grégoriennes, XXVI, 1998, pp. 173-204.

${ }^{109}$ Manuel Pedro Ferreira: "Conclusit vias meas inimicus: un répons wisigothique en Gaule", Cahiers de Civilisation Médiévale, 58, 2015, pp. 231-238; M. A. López Fernández: Los Cantorales..., pp. 161-165; también hay intentos y algunas especulaciones en diferentes foros científicos, como "Let's Compose Mozarabic Melodies" (Musicologie Médiévale https://gregorian-chant.ning.com/, consulta 1-12-2019).

${ }^{110}$ Las partituras no se conservan en el Archivo de Montserrat, donde vivió Prado hasta 1976, ni en el Fondo Pérez de Urbel, del Valle de los Caídos, ni tampoco en el Archivo del Monasterio de Silos. 
Las restauraciones artísticas y musicales en las ceremonias de 1942 y 1943

Para entender cómo se llegó a la reconstrucción de las melodías interpretadas en la ceremonia de 1939 recurriremos a un caso posterior pero muy similar del que tenemos más información, pues los benedictinos de Silos interpretaron una "misa mozárabe" en otras ceremonias franquistas. La primera de ellas fue la "Consagración de la Cámara Santa" celebrada en Oviedo en septiembre de 1942. La siguiente fue el "Milenario de Castilla", que se celebró en Covarrubias en agosto de 1943. La última, el "Centenario de la muerte de San Benito", celebrado en el monasterio de Santo Domingo de Silos en 1956. Además de en estos actos multitudinarios, el coro de Silos interpretó piezas "mozárabes" en otras ocasiones y grabó algunos discos con este repertorio, como veremos.

La ceremonia de Oviedo de 1942 celebró la consagración de la Cámara Santa y la restitución a ella de la Cruz de laVictoria -restauradas ambas después de la voladura sufrida durante la revolución de 1934- así como el undécimo centenario de Alfonso II. Los actos duraron varios días y la prensa local dio cumplida y abundante cuenta de todos los detalles.

El sábado 5 de septiembre de 1942, a las diez y media de la mañana y antes de la llegada de Franco, se celebró una "misa mozárabe" interpretada por un coro de voces del Seminario dirigidos por Germán Prado ${ }^{111}$, acompañado seguramente por monjes de Silos - aunque no se menciona-, puesto que también estaba presente su abad. A la misa asistieron los más altos representantes del clero, la política y el ejército:

En la presidencia de honor figuraban los generales Aranda,Valdés Cabanilles y Recas; coronel Caballero, Alcalde, Corporación municipal, Diputación provincial, Audiencia, Universidad, Falange y representaciones de los Ayuntamientos de Bilbao, San Sebastián y Vitoria, Pamplona, León, Salamanca y Toulouse. El nuncio de su Santidad, monseñor Cicognani ocupaba un lugar de honor en el presbiterio y a su lado se sentaban los obispos de León, Lugo, Tuy, Coria y Salamanca y los abades mitrados de Samos y Silos ${ }^{112}$.

Franco llegó a Oviedo la mañana del día 5 después de la misa y, a las cuatro y media de la tarde, el "cortejo real"113 celebró la procesión de traslado de las reliquias a la Cámara Santa, en la que el propio caudillo llevó la Cruz de laVictoria en su último tramo. También en este caso estuvieron presentes importantes reliquias y grandes masas, con más de cinco mil peregrinos - muchos de ellos trabajadores que se desplazaron "espontáneamente" ${ }^{114}$, pues se les habían concedido

${ }^{111}$ La Nueva España, 6-9-1942, p. 1.

${ }^{112}$ ABC, 6-9-1942, p. 8.

${ }^{113}$ Así lo llama La Nueva España, 3-9-1942, p. 2.

114 Tan espontáneamente como el régimen organizaba sus manifestaciones, por ejemplo G. Di Febo: Ritos de guerra..., p. 104, cita el texto de Dionisio Ridruejo en la "Orden de la campaña que ha de realizarse en Madrid en los primeros días de la entrada” [del ejército sublevado], Burgos, 15-2-1939. Archivo General de la Administración, Cultura, caja 1346, “[...] se procurará la organización de manifestaciones 
permisos y abono de jornales para el desplazamiento ${ }^{115}$ - y unas veinte mil personas en la procesión ${ }^{116}$. El día siguiente hubo un desfile, la firma del acta de la consagración de la Cámara y numerosos actos, inauguraciones y visitas, tanto en Oviedo como en Gijón. El lunes 7 Franco asistió a una misa de Requiem oficiada por el abad de Silos en la Capilla de los Reyes Caudillos de la Catedral, inauguró la Plaza de los Reyes Caudillos de la Reconquista -nótese de nuevo el simbolismo- y descubrió sus estatuas ${ }^{117}$.

La reconstrucción de los monumentos asturianos fue para el franquismo un arma ideológica ${ }^{118}$ con la que ejerció un papel similar al de la monarquía asturiana medieval cuando Alfonso II recreó en Oviedo "el orden y ceremonial de los godos, tal como había sido en Toledo". Precisamente los dos reyes restauradores del Ordo Gothorum, Alfonso II y Alfonso III, habían donado las cruces restauradas, el primero la de los Ángeles y el segundo la de la Victoria, la que había sido enarbolada por Pelayo y que Franco portó en procesión. De nuevo se asoció la figura de Franco con la realeza, ahora con la Monarquía Asturiana -Pelayo y los Alfonsos-, y se insistió en el mozarabismo de Asturias. Así, el 3 de septiembre Germán Prado había impartido una conferencia sobre "Valores artísticos de la misa mozárabe" 119 en la que señaló que "en Asturias se conservó más que en ningún otro sitio la tradición mozárabe", algo sobre lo que insistió la prensa al decir, refiriéndose a la "Misa mozárabe", "los asturianos tienen un concepto entrañable de lo vernáculo" 120 . También la prensa asoció sin disimulo a Franco con Pelayo:

Con mano firme, aunque el corazón vacile estrangulado por la emoción que le asoma a la cara, el Caudillo de España porta la Cruz de la Victoria, la misma que un día, en las peñas del Auseva, mantuvieron, también con imbatible firmeza, las manos de Pelayo, que inició una reconquista que tanta similitud tiene con la que inició en julio de mil novecientos treinta y seis nuestro Caudillo ${ }^{121}$.

La restauración de la Cámara Santa se llevó a cabo bajo la dirección de Luis Menéndez Pidal, como expresa García Cuetos en magistral síntesis, "[mezclando] materiales nuevos y originales en perfecta confusión" ${ }^{22}$. Las joyas de la catedral por su parte - la Cruz de los Ángeles, la de la Victoria y la Caja de

espontáneas haciendo salir a la calle todo el pueblo de Madrid".

${ }^{115}$ La Nueva España, 4-9-1942, p. 2.

${ }^{116} A B C, 6-9-1942$, p. 8.

${ }^{117} A B C, 7-9-1942$, p. 9.

${ }^{118}$ María Pilar García Cuetos: "La restauración del Prerrománico asturiano. Luis Menéndez Pidal", La intervención en la arquitectura prerrománica asturiana, Jorge Hevia Blanco (coord.), Oviedo, Servicio de Publicaciones de la Universidad de Oviedo, 1997, pp. 119-136 (p. 128).

${ }^{119}$ La Nueva España, 4-9-1942, p. 4.

${ }^{120} \mathrm{Ibid}$., p. 1 (las cursivas son mías).

${ }^{121}$ La Nueva España, 6-9-1942, p. 1.

${ }^{122}$ María Pilar García Cuetos: El prerrománico asturiano: historia y restauración, Oviedo, Sueve, 1999, p. 160. 
las Ágatas- no se empezaron a restaurar hasta el mismo año de 1942, en la joyería Pedro Álvarez de Oviedo, con pocos medios, sin documentación gráfica adecuada y con precipitación, para poder tenerlas a tiempo en la visita de Franco, que coincidía con el centenario de Alfonso II y con el día de San Miguel, a quien estaba dedicada la capilla superior de la Cámara. Así, para la Cruz de los Ángeles hubo que colocar piedras modernas y, como no había suficientes, se añadieron fragmentos de puños de paraguas de diferentes colores. La Cruz de la Victoria no había sufrido muchos daños, pero le faltaban numerosos cristalitos verdes que rellenaban los triforios y se sustituyeron por vidrios tallados uno a uno a medida para cada alveolo. Los vidrios se obtuvieron de un objeto de vidrio verde también muy tradicional y muy asturiano: Franco enarboló con orgullo el símbolo de la victoria flamantemente restaurado con trozos de botellas de sidra ${ }^{123}$.

En esta ceremonia de consagración de la Cámara Santa y restitución de la Cruz de la Victoria, se cantó una "misa mozárabe" que Prado tuvo que reconstruir, pues no se pudieron interpretar las mismas piezas, tan específicas, de 1939. Los textos de esa misa se editaron en un folleto con ocasión de la ceremonia del "Milenario de Castilla" de $1943^{124}$ y las melodías en un cuadernillo de siete páginas - sin fecha-, en el que están copiadas a mano, en notación cuadrada, todas las piezas necesarias para interpretar una "misa mozárabe", aunque no en el orden litúrgico correspondiente (ilustración 8). Las melodías proceden en su mayor parte (véase tabla 5) de los Cantorales Mozárabes de Cisneros, del siglo XVI, con la única excepción de un Gloria del Antifonario de León reconstruido por Prado en $1933^{125}$. El propio Prado afirma que las melodías de los Cantorales "son monótonas en su mayor parte, con frecuencia faltas de inspiración, y en la modalidad y en ciertas terminaciones agudas, algo extravagantes. Sin embargo, hay unas cuantas que no desmerecen comparadas con las melopeas auténticas del repertorio visigótico y del gregoriano, ocupando un lugar honroso en el antifonario de la capilla mozárabe"126. Así pues, para reconstruir la "misa mozárabe", transcribió algunas de estas melodías de los Cantorales, las que consideró más genuinas y de mayor calidad (ilustración 9).

${ }^{123}$ La información sobre la restauración procede de Carlos Cid Priego: "Notas y recuerdos del robo, desperfectos y restauraciones de las joyas prerrománicas asturianas de la Cámara Santa de Oviedo", Anuario del Departamento de Historia y Teoría del Arte (UAM), VII-VIII, 1995-1996, pp. 32-34.

${ }^{124}$ Se trata de un folleto de 37 páginas con una introducción titulada "Origen y estructura de la Misa Mozárabe" (pp. 3-5), redactado por Prado con los textos completos de la misa. Misa mozárabe en el milenario de Castilla (943-1943) oficiada en Covarrubias por los Padres Benedictinos de Silos el 22 de agosto de 1943, Burgos, Imprenta Aldecoa, 1943.

125 Germán Prado: "Una nueva recensión del himno Gloria in excelsis", Ephemerides Liturgicae, 46, 1932, pp. 481-486; —: "Un Gloria in excelsis mozárabe", Revue Grégorienne, XVIII, 1933, pp. 15-19; _.: "El Kyrial español", Analecta Sacra Tarraconensia, 14, 1941, pp. 97-128; —: idem, 15, 1, 1942, pp. 46 y ss.

${ }^{126}$ C. Rojo, G. Prado: El canto mozárabe, p. 105. 
Tabla 5. Piezas de la "Misa mozárabe" en el cuadernillo de Prado

\begin{tabular}{|c|c|c|}
\hline Pieza & Fuente & Publicada en \\
\hline Per gloriam & Cantoral C, f. 1 & Rojo y Prado 1929, p. 120 \\
\hline Gloria & Antifonario de León, f. 297 & Prado 1933 \\
\hline Lectio Iheremia & Cantoral C, f. 31 (entonación) & \\
\hline Lectio epistola & Cantoral C, f. 31 & \\
\hline Lectio evangeli & Cantoral C, f. 31v & \\
\hline R. Adiuvate me & Missale Mixtum 1500 & Rojo y Prado 1929, p. 117 \\
\hline Agios, agios & Cantoral C, f. 33 & \\
\hline Offerunt pro se & Cantoral C, f. 33 & \\
\hline Pacem meam & Cantoral A, f. 187 y B, f. 5 & Rojo y Prado 1929, p. 119 \\
\hline Introibo ad altare & Cantoral C, f. 16v & \\
\hline R. Ad deum qui letificant & Cantoral C, f. 34r & \\
\hline Habemus ad Dominum & Cantoral C, f. $34 \mathrm{r}$ & \\
\hline Sanctus & Cantoral A, f. 189 & \\
\hline Gustate et videte & Cantoral B f. 9v & Rojo y Prado 1929, p. 130 \\
\hline Ant. Refecti Christi & Cantoral B f. 11v & \\
\hline Credo & Cantoral B 1,7 & Rojo y Prado 1929, p. 123 \\
\hline Trisagio Sanctus Deus & Cantoral A f. 126v & \\
\hline Prelegendum Dominum regnavit & Cantoral A, f. 171v & \\
\hline Psallendum Circumdabo altare tuum & Cantoral A f. $179 \mathrm{v}$ & \\
\hline Laudas Alleluia Qui posuit & Cantoral A f. 180r & \\
\hline Sacrificium Alleluia Oblatio Domini & Cantoral A, f. $180 \mathrm{v}$ & \\
\hline
\end{tabular}
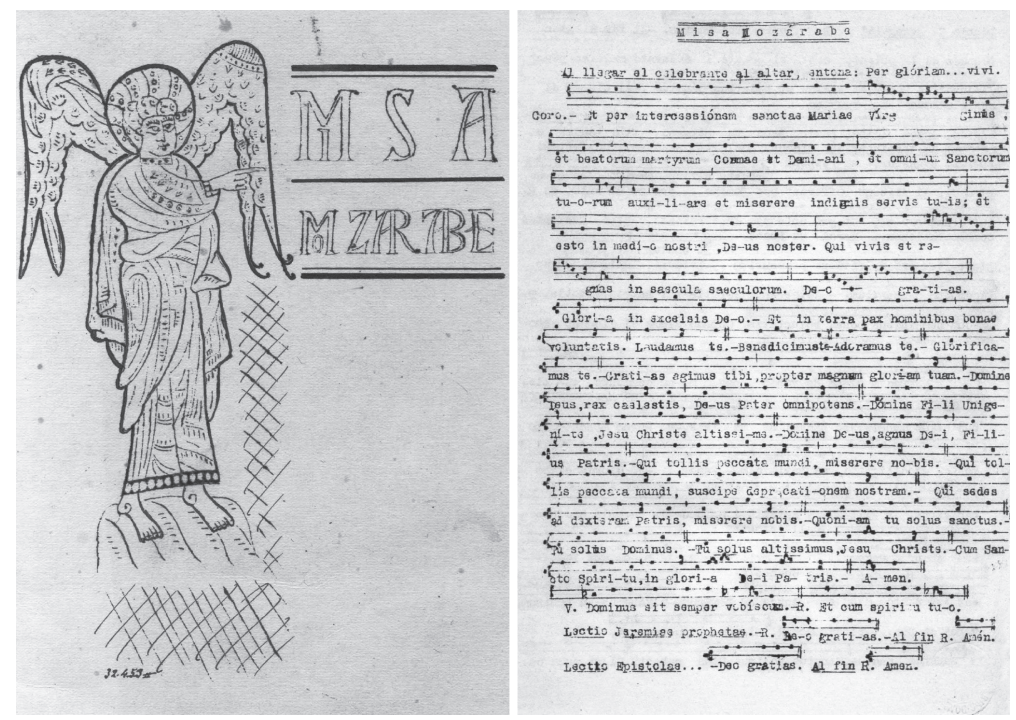

Ilustración 8. Prado cuadernillo con la Misa Mozárabe (Ismael Fernández de la Cuesta, archivo particular) 
La única pieza del cuadernillo de Prado que no procede de los Cantorales de Cisneros es el Gloria del Antifonario de León, en notación hispánica adiastemática, en principio intranscribible (ilustración 10). De él, Germán Prado dice:

Venciendo una repugnancia algo justificada, hemos ensayado una transcripción de los neumas mozárabes in campo aperto, porque no ha perdido un ápice de su triste virtualidad aquel viejo y trillado axioma: "neuma sine lineis, puteum sine fune". Mas, por otra parte, disminuían nuestro escrúpulo los esfuerzos de la diastematía por romper su enigmático silencio [...].

Tal vez no hemos acertado con la modalidad ni con las cadencias. Nada de extraño tendría, cuando los que estaban más cerca que nosotros a la tradición melódica y pudieron fielmente reflejarla, se extravían no pocas veces en sus traducciones de la línea auténtica primitiva, que no pudo ser si no una. ¿De dónde provienen si no tantas y tan notables variantes como hay entre los distintos manuscritos? [...].

El simplićsimo recitado de nuestro Gloria mozárabe sigue el diseño Mi-sol-la ------- la-si-sol-la, diseño tan frecuente en el repertorio de todos los ritos cristianos, como que tiene raigambre innegablemente primitiva. Es el leit-motif del "Te Deum" romano, del "Gloria in excelsis" n. 15, atribuido ahora a las fiestas simples, y que nunca falta en los antiguos troparios. Es también el motivo básico del "Pater noster" mozárabe, de las Lamentaciones españolas, etc., etc. Solo al fin se sale del carril para terminar con una modulación tan inesperada como original ${ }^{127}$.

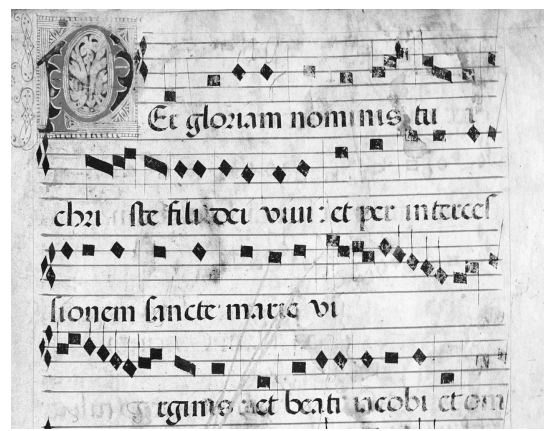

Ilustración 9. Inicio de la Misa en el Cantoral Mozárabe C,f. 1

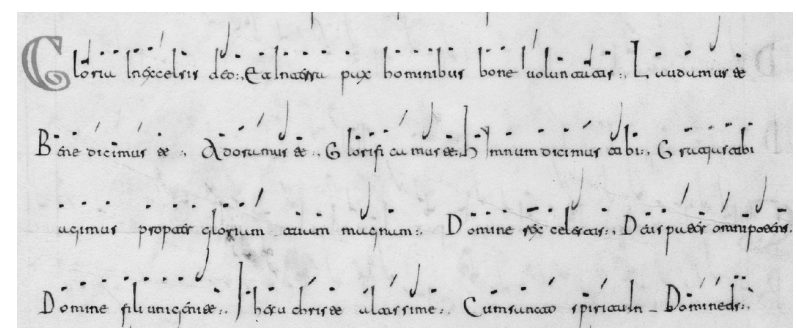

Ilustración 10. Inicio del Gloria del Antifonario de León, f. $297 r$

\footnotetext{
${ }^{127}$ G. Prado: "Una nueva recensión...”, p. 485.
} 
Años después y bajo la dirección de Ismael Fernández de la Cuesta, el coro de Silos grabó tres discos -sin contar reediciones y remasterizaciones- con repertorio "mozárabe": Misa Mozárabe (1966), Liturgia española antigua (1968) y Códice Calixtino y Antifonario Mozárabe (1969). La primera grabación contiene parte del cuadernillo "Misa mozárabe", incluido el Gloria de León;la segunda incluye casi exclusivamente piezas de los Cantorales de Cisneros -algunas del cuadernillo, otras transcritas por Prado ${ }^{128}$ y tres nuevas, tomadas del Misal de Cisneros de 1500, Pater noster (f. 226), Ecclesiam sanctam (f. 224v) y Per misericordiam (f. 225)-a las que añaden las Lamentaciones de Jeremías del Antifonario de Silos (E-SI 9), de rito romano, pero con tonos ajenos al gregoriano -que por ello se consideran hispánicos $-{ }^{129}$, y varias piezas del ordinario tomadas de manuscritos españoles de rito romano ${ }^{130}$. En las notas a este disco explica el director:

Para la "Misa mozárabe" contenida en este disco hemos elegido las piezas contenidas en los libros que nos han parecido de una mayor autenticidad, a la vez que poseen un más señalado valor musical. [...] Nos ha sido posible restablecer una construcción que suponemos la más extendida dentro de la Eucaristía mozárabe merced al manuscrito n. ${ }^{\circ} 4$ de la colección de Silos (siglo XI), donde está contenida la notación completa de diversas misas. En el disco se incluye solamente un extracto: no hubiera sido posible la realización de la misa completa en una sola pieza discográfica y, por otra parte, existen en el conjunto diversas partes que no se relacionan en realidad con la música misma, aparte de otras que, probablemente, ignoramos. Los diversos fragmentos recogidos no tienen igual procedencia, pero cada uno de ellos ha sido colocado dentro del lugar que le corresponde en el conjunto de la estructura general ${ }^{131}$.

La tercera grabación incluye como piezas "mozárabes" las Lamentaciones de Jeremías y el Gloria de León. De este Gloria dice Roberto Pla en las notas al disco:

[en este repertorio] la altura de los sonidos solo puede obtenerse por conjetura. No obstante, el benedictino Germán Prado, monje de Silos, ha intentado la transcripción de algunos fragmentos. A título de mera suposición completamos este disco con un ejemplo bellísimo del Códice leonés; un Gloria pleno de inspiración artística y elevación mística.

De su propio testimonio y de la observación de Pla, se deduce que Prado reconstruyó la pieza en base a su conocimiento del repertorio y su intuición "a título de mera suposición", tomando como base un diseño melódico relativamente frecuente en el canto romano y el neomozárabe de Cisneros ${ }^{132}$. De la

${ }^{128}$ C. Rojo, G. Prado: El canto mozárabe, pp. 106-140.

${ }^{129}$ Publicadas por Rojo y revisadas por Prado. Casiano Rojo: Cantus Lamentationum apud hispanos usurpatus, Bilbao, Eléxpuru, 1917; — : "The Gregorian Antiphonary of Silos and the Spanish Melody of the Lamentations”, Speculum, V, 1930, pp. 306-324; G. Prado: Cantus Lamentationum. .

${ }^{130}$ Editadas en Germán Prado: Kyriale Hispanicum, París, Tournai / Roma, Desclée \& Socii, 1935.

${ }^{131}$ Notas de Ismael Fernández de la Cuesta: "Gregorianischer Choral. Canto gregoriano. Liturgia española antigua", Monasterio de Santo Domingo de Silos, Archiv Produktion (LP), Madrid, 1991.

132 Testigos presenciales recuerdan que Prado "cantaba" leyendo los neumas por el Antifonario de León. Información oral de Don Randel (10-4-2019) e Ismael Fernández de la Cuesta (24-5-2019). 
misma manera debió reconstruir todo el repertorio musical de la ceremonia de la Salesas de 1939.

La ceremonia de 1939 tuvo todo el carácter de una investidura real, y la propaganda del régimen se encargó de transmitir esta información para que fuera más efectiva. Desde entonces, se repitió a menudo la idea de la restauración y recuperación de antiguas ceremonias, ritos, espacios y reliquias para insistir en una idea nuclear: Franco, como Wamba, era el caudillo vitalicio, consagrado por la iglesia para ejecutar la misión divina que se le había encomendado. Recordemos que la unción se otorgaba a los reyes godos elegidos por el ejército que carecían de la legitimación dinástica hereditaria. La unción revestía, además, de un carácter sagrado que ensalzaba al ungido por encima de sus súbditos y demonizaba la rebelión o la protesta. Como afirman Quirós Castillo y Tejerizo-García, la epopeya visigoda y la creación de la primera España se introdujeron plenamente en el discurso institucional. Así, por ejemplo, en su discurso de mayo de 1941, durante la creación de la Asociación Hispano-Germana, el General Moscardó dijo: "Los Movimientos que impulsan el Orden Nuevo en Europa se apoyan, y no parvamente, en el elemento histórico: cuando hemos requerido salvarnos hemos hecho, por doquier, milicia, y exaltamos un Jefe, como el viejo pueblo que fundió en España lo indígena, lo romano y lo germánico para darnos por primera vez unidad"133.

¿Sería Franco consciente en 1939 de la refinada manera en la que estaba mostrando al mundo la legitimación de su poder recién adquirido? A este respecto resulta significativo su discurso en el cóctel que se sirvió a los militares en el Banco de España el 20 de mayo, después de la ceremonia, y en el que se presentó como paladín de una nueva-vieja- aristocracia de las armas, como caudillo elegido por su ejército:

"Nosotros tenemos ahora que derribar la frivolidad de un siglo, que desterrar hasta los últimos vestigios del fatal espíritu de la Enciclopedia. La aristocracia se forjó en las batallas endureciendo la mano sobre el puño de la espada y no en los salones. Cuando los viejos guerreros se pusieron guante blanco y comenzaron a hacer reverencias de corte decayó la aristocracia. Pero hoy tenemos una aristocracia magnífica, cuyas manos han encallecido también en el uso de las armas. $\mathrm{Mu}-$ chas veces se ha hablado de Imperio y yo os afirmo que esta no es una palabra hueca, porque ha de forjarlo nuestra magnífica juventud" [...].

Una enorme ovación acogió estas últimas palabras del Caudillo ${ }^{134}$.

${ }^{133}$ Juan Antonio Quirós Castillo, Carlos Tejerizo-García: "El reino de los visigodos y 'la primera España'. El rol de la arqueología en la creación de narrativas legitimadoras", Archeologia Medievale, XLVI, 2019, pp. 54-55. Los autores toman la cita de Francisco Gracia Alonso: "La arqueología durante el franquismo. Instrumentalización identitaria", Los intelectuales y la dictadura franquista. Cultura y poder en España de 1939 a 1975, Madrid, Pablo Iglesias, 2014, p. 58.

${ }^{134}$ Heraldo de Zamora, 22-5-1939, p. 1. 


\section{Conclusiones}

Los mozárabes toledanos eran conscientes desde el siglo XII de tener un privilegio a causa de su liturgia particular y por ello recopiaron sus códices imitando los antiguos hasta bien entrado el siglo XIV, cuando parece que la permanencia del rito flaqueó por la escasez de parroquianos. En su rescate vino la edición cisneriana de textos y melodías, que podemos considerar la primera gran manipulación realizada para reinventar la tradición "mozárabe" desaparecida, pues en los Cantorales se escribieron cientos de melodías sin relación ninguna con las originales y también los textos tienen mucho de nuevo ${ }^{135}$.A la edición de los textos de Cisneros se le da, además, el apelativo de "isidoriana" para relacionarla con los padres de la iglesia visigótica (Misal y Breviario secundum regulam beati Isidori, véase nota 8). Esta restauración -que ya tiene mucho de invención- permitía mantener la tradición "mozárabe" a pesar de que, aun teniendo a su disposición los Cantorales, los capellanes mozárabes de Toledo no cantaban lo que estaba escrito en los libros, sino una simplificación realizada por ellos mismos que se le parecía muy poco ${ }^{136}$.

En el siglo XVIII, el jesuita Andrés Marcos Burriel encargó la copia en un lujoso facsímil de un manuscrito litúrgico hispánico toledano para regalárselo al rey, y menciona en su presentación cómo ese libro -en representación de los demás- es una prueba incontrovertible de la continuidad de la liturgia mantenida en Toledo desde los visigodos, a los que considera predecesores de los Borbones. En la ceremonia de acción de gracias de 1939, el régimen franquista escoge el rito hispánico para representar la continuidad de Franco con los monarcas históricos españoles y las melodías cantadas en esa ocasión fueron algunas como aquellas que Germán Prado "leía" en el Antifonario de León, lo cual -con el máximo respeto a su enorme sabiduría musical- es imposible sin una gran dosis de creatividad.

Así pues, la liturgia hispánica se ha empleado ya desde el siglo XII como elemento de una presunta "identidad hispana" y se le ha dado a menudo un sentido simbólico y político. Como una liturgia no está completa sin su músi-

${ }^{135}$ El canónigo Ortiz, editor de los textos, dice en el Prefacio del Missale mixtum... de 1500, que tuvo que realizar una ingente tarea editorial recopilando fuentes, reorganizando textos, corrigiendo errores, completando lagunas, resolviendo dudas... y todo ello con manuscritos tan difíciles de leer que incluso a un experto le costaba reconocer la misma frase en dos lugares diferentes. Las numerosas diferencias entre los manuscritos hispánicos y la edición de Ortiz han sido estudiadas por Louis Brou: "Études sur le Missel et le Bréviaire 'mozárabes’ imprimés", Hispania Sacra, 11, 1958, pp. 349-398; José María Martín Patino: "El Breviarium mozárabe de Ortiz: su valor documental para la historia del oficio catedralicio hispánico", Miscelánea Comillas, 50, 1963, pp. 209-297; Jordi Pinell: "El problema de las dos tradiciones del antiguo rito hispánico. Valoración documental de la tradición B, en vista a una eventual revisión del ordinario de la misa mozárabe", Liturgia y música mozárabes. Ponencias y comunicaciones presentadas al I Congreso Internacional de Estudios Mozárabes, Toledo, 1975, Toledo, Instituto de Estudios Visigótico-Mozárabes de San Eugenio, 1978, pp. 3-44.

${ }^{136}$ C. J. Gutiérrez: "El canto mozárabe...", p. 193. 
ca y la de esta no se conserva, en varias ocasiones se han creado melodías para hacerla sonar. Parece pues estar claro que no importa demasiado lo que suene dentro de la etiqueta "canto hispánico" o "mozárabe", sino lo que representa y simboliza esa etiqueta, aunque sea necesario explicarlo por medio de comunicados de prensa.

Recibido: $18-3-2020$

Aceptado: $16-5-2020$ 